\title{
Connessioni geometriche: per una catalogazione 'fantastica' dei pattern bizantini
}

Marinella Arena

\section{Abstract}

Lo studio ha per tema l'iconografia delle chiese bizantine nel Mediterraneo e s'inserisce in un progetto di ricerca più ampio, dedicato all'architettura religiosa di matrice orientale realizzata fra il IX e il XVI secolo. La metodologia di ricerca è basata su: rilievo strumentale e fotografico; analisi e catalogazione degli apparati iconografici e decorativi; comunicazione visuale dei dati e delle connessioni rintracciate.

Parole chiave

Mediterraneo, pattern geometrici, iconografia bizantina, catalogazione.

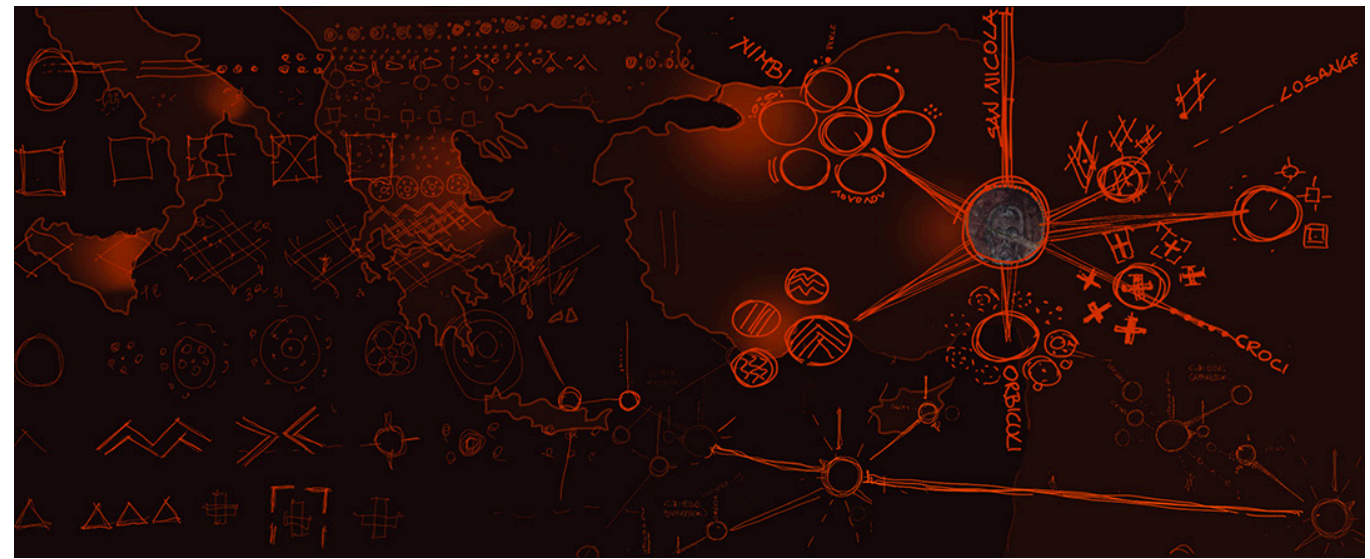




\section{Introduzione}

Nel Mediterraneo le connessioni sono fili tesi fra città dimenticate e porti vitali, fra architetture auliche e dettagli vernacolari. Essi disegnano un tessuto cangiante, complesso, tridimensionale, dove i nuovi orditi si riallacciano alle vecchie trame. Quando l'impero bizantino supera i limiti dell'Egeo e si riversa in tutto il Mediterraneo, impalpabili fibre seriche, intrise di chermes, indaco e pernambuco, sostituiscono quelle ruvide e logore del passato e propongono nuovi modelli culturali.

Questa ricerca prende spunto dalle trame di riferimenti formali ed estetici che la cultura bizantina diffonde nel Mediterraneo, e in particolar modo fra lo lonio e l'Egeo, per implementare la documentazione e la divulgazione dell'apparato iconografico presente nelle chiese rupestri e in quelle sub divo [I]. Le chiese bizantine erano completamente affrescate, la complessità e la molteplicità dei segni che animavano lo spazio sacro formavano una trama densa di riferimenti, sacri e pagani; teologici e stilistici; geografici e culturali. I fili che in passato erano il tramite fra significante e significato, sono adesso logorati, in alcuni casi spezzati, dal tempo e dal disuso.

La strategia operativa di questa ricerca si concentra su alcuni aspetti dell'iconografia sacra ipotizzando una catalogazione 'fantastica' dei pattern geometrici, capace di riannodare alcuni di quei fili. Lo studio, animato da un approccio giocoso, volto alla comunicazione e alla valorizzazione da un lato sottolinea le connessioni visuali presenti del complesso apparato iconografico delle architetture bizantine e dall'altro ricostruisce, attraverso un abaco tipologico, una "geografia artistica" [2] dei pattern geometrici.

Fig. I. Localizzazione dei riferimenti formali analizzati e dei rilievi effettuati.

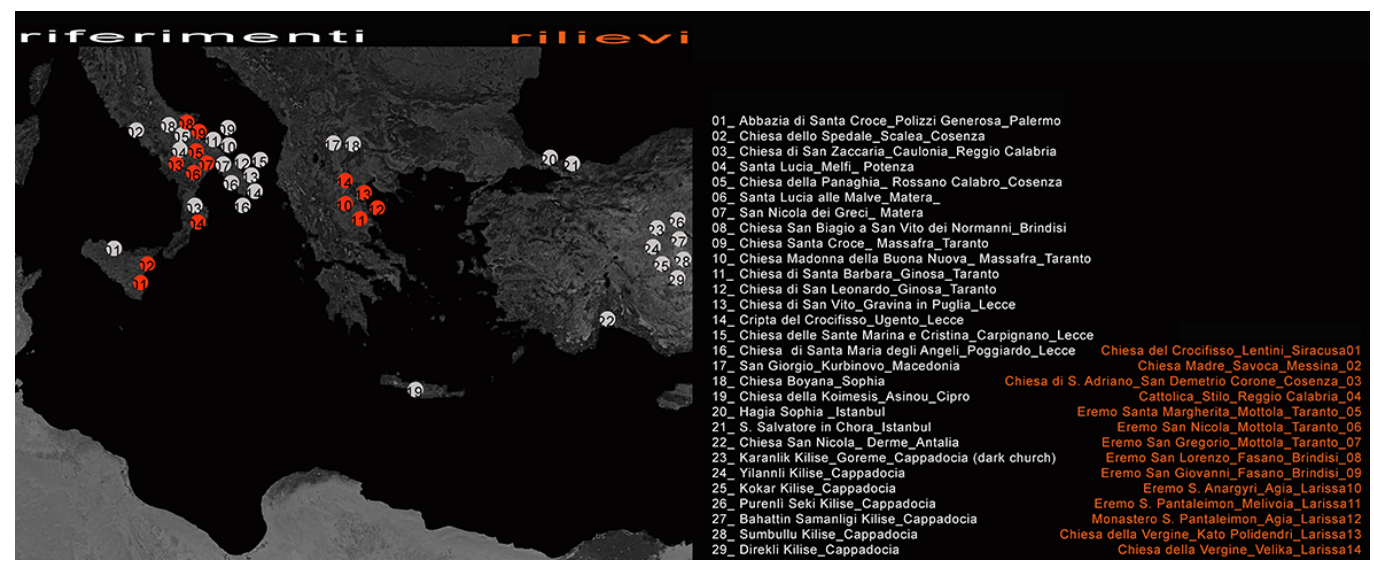

\section{Stato dell'arte}

Sono poche le chiese bizantine che hanno conservato intatta la struttura architettonica e l'apparato iconografico. Infatti, il passaggio dal rito orientale a quello latino ha comportato spesso la modifica o la completa distruzione degli edifici. Viceversa là dove il rito si è mantenuto orientale, in Grecia ad esempio, i numerosi rimaneggiamenti per adeguare lo spazio alle moderne esigenze del culto hanno compromesso l'autenticità e la riconoscibilità del linguaggio architettonico.

Le architetture sacre rupestri, il nucleo di questa ricerca, sono quelle che meglio hanno conservato, grazie al sostanziale abbandono, la conformazione originaria e l'apparato decorativo [3]. La maggior parte degli affreschi rinvenuti presenta comunque gravi lacune e distacchi causati dall'incuria e dai numerosi deliberati danneggiamenti. La fruizione, come del resto la 
comprensione, degli affreschi è dunque difficile e lacunosa per motivi oggettivi e culturali. L'arte iconografica bizantina è un fenomeno complesso, tanto da spingere uno dei suoi massimi studiosi ad affermare: "allo stato attuale delle nostre conoscenze non siamo in grado di stabilire legami tra le opere d'arte conservate e la struttura sociale o la geografia bizantina $[. .$.$] alcuni fatti generali stanno a rafforzare questo atteggiamento pessimistico:$ l'anonimato sistematico delle opere bizantine; l'estrema scarsità delle fonti scritte in seguito alla distruzione della quasi totalità degli archivi; infine l'insufficiente differenziazione delle opere tra loro" [4].

Come si può pensare di affrontare una catalogazione, e una sistematizzazione, in un quadro di così grande incertezza? Lo spirito di questa ricerca, interno alla disciplina del disegno, è quello di prendere spunto dai rilievi fatti per tendere, illustrandoli, alcuni dei fili che legano stilemi, dettagli e iconografie sacre. La classificazione è pertanto 'fantastica' e parziale, proprio perché, pur poggiando su criteri storici e documentali, accosta architetture, immagini, pattern con criteri morfologici, proporzionali e tipologici.

Nello specifico saranno analizzate, come esemplificazione del processo di analisi e di descrizione, le rappresentazioni di alcuni santi e la struttura dei pattern geometrici. Questi ultimi sono un tratto distintivo dell'iconografia bizantina e meritano un approfondimento utile a una sistematizzazione prettamente morfologica [5].

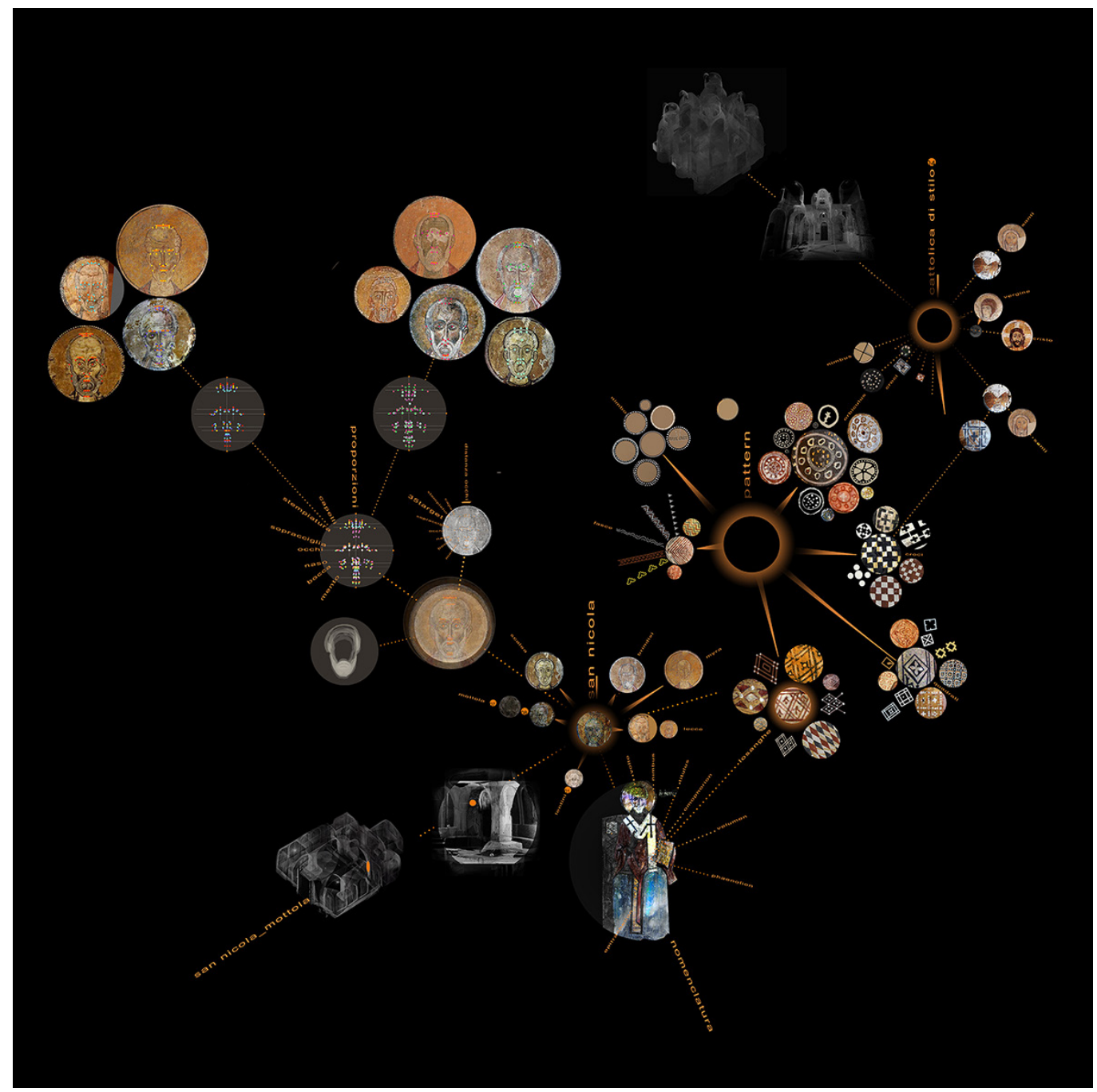




\section{Metodologia della ricerca}

La strategia della ricerca prevede diversi passaggi: individuazione dei casi di studio più pertinenti alla tematica prescelta (fig. I); il rilievo strumentale e diretto; analisi e catalogazione dei manufatti, proposta per una nuova catalogazione finalizzata alla valorizzazione e alla comunicazione dei beni [6]. Le architetture inserite nella ricerca presentano un apparato iconografico leggibile, con una datazione compresa fra il IX e il XIV secolo, e appartengono all'antico Thema di Sikelia, (trasformato dopo la conquista araba in Thema di Calabria) al Thema di Langobardia (l'attuale Puglia), e al Thema di Hellas, nella Tessaglia. II rilievo strumentale, e quello fotografico, consentono una buona base per la costruzione di un data base che illustra la collocazione spaziale dell'iconografia sacra all'interno degli edifici.

La prima parte prevede la localizzazione e la visualizzazione grafica delle interconnessioni relative alle figure principali dei Santi e dei pattern ricorrenti all'interno delle architetture rilevate (fig. 2).

La seconda fase esegue una catalogazione tipologica e geometrica per individuare la forma e le corrette proporzioni del pattern. In questa fase le scansioni laser sono state implementate da immagini ad alta risoluzione per una migliore analisi della forma e della dimensione dei pattern geometrici (fig. 7).

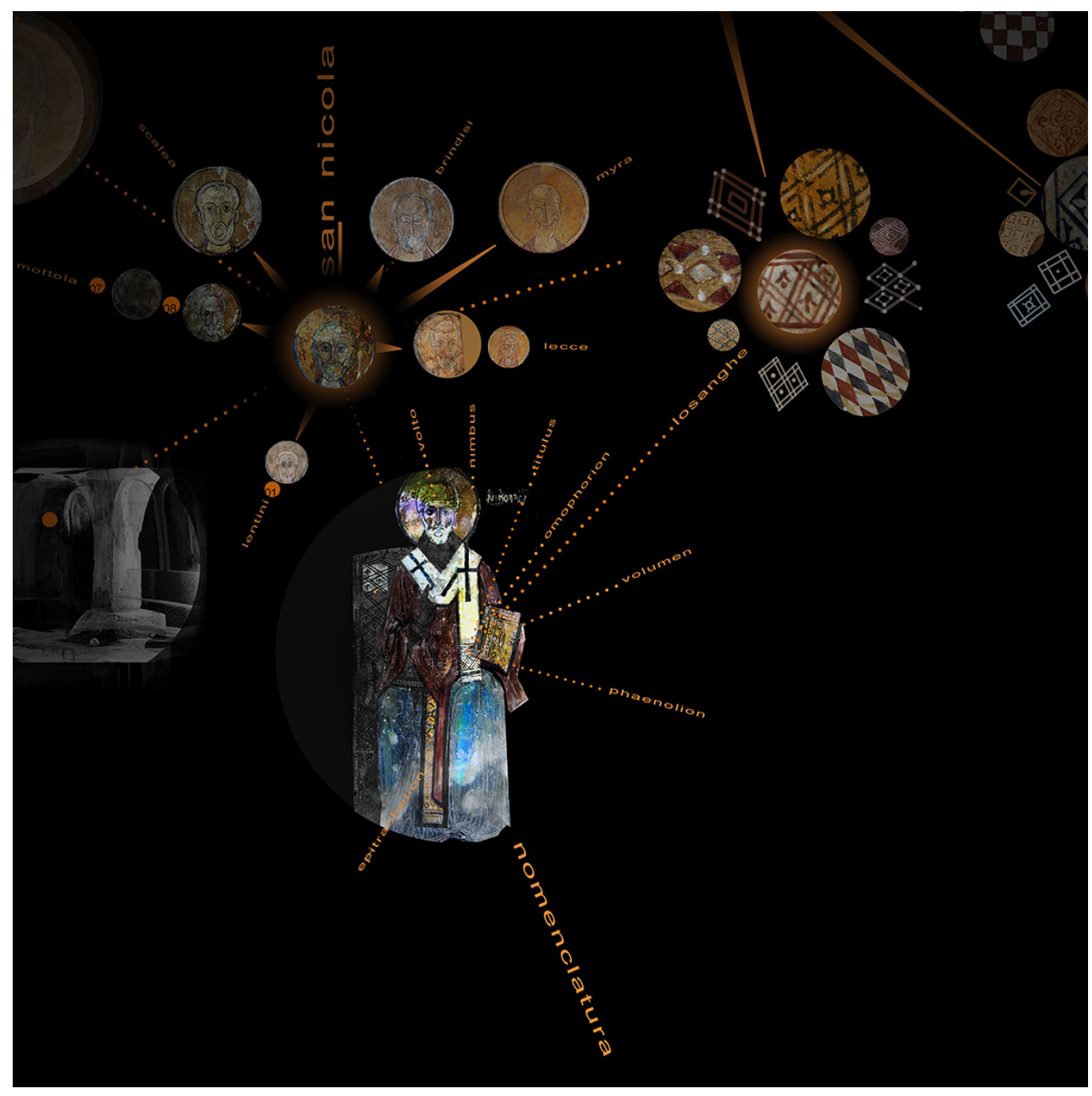




\section{Connessioni}

Le connessioni che legano le architetture rilevate e le rappresentazioni iconografiche sono multiple ed espresse graficamente (fig. 2). Come caso studio si è scelto di illustrare la figura di San Nicola di Myra, molto diffusa nell'Italia meridionale e legata anche al paese di origine, l'antico Thema di Kibyrrhaioton, attuale Derme.

La struttura grafica di questa ricerca prevede un unico flusso d'immagini che consente, con semplicità, di passare dall'effige del santo alla sua collocazione nell'omonima chiesa [7]; alla relativa nomenclatura; alle altre rappresentazioni dello stesso santo; all'apparato decorativo che lo definisce. Da ogni elemento può scaturire una nuova connessione, ad esempio dalla decorazione delle vesti del santo si passa ai pattern geometrici, da questi ai decori cruciformi e da questi, tramite la veste vescovile polistavrion, a uno dei padri della chiesa d'oriente, San Giovanni Crisostomo, nella Cattolica di Stilo. (fig. 3). Le connessioni descritte sono sicuramente parziali e lacunose, ma illustrano un percorso visuale, potenzialmente infinito, fra elementi affini.

Uno degli obiettivi della ricerca punta a semplificare il riconoscimento dei santi attraverso un approccio visuale, diretto e intuitivo. Infatti, l'identità dei santi bizantini è spesso di difficile attribuzione [8] sia per i danneggiamenti subiti, gli affreschi presentano distacchi e mancanze proprio sul volto del santo, sia per l'omogeneità e l'astrazione delle rappresentazioni.

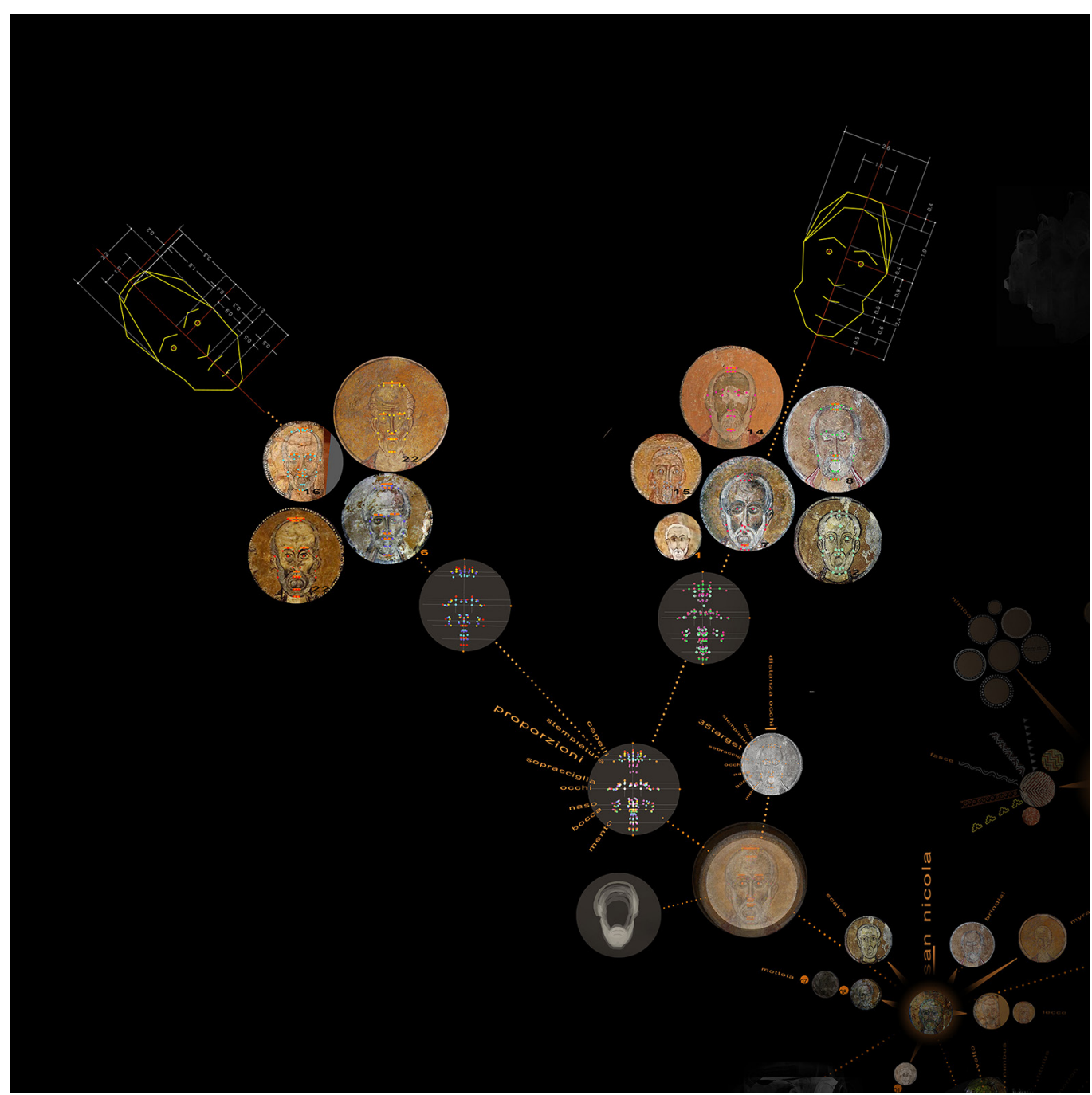


La ripetizione stereotipata di alcuni aspetti legati alliconografia dei santi, del Cristo o della Madonna, è il tentativo di separare la rappresentazione sacra dalla mimesi della realtà puntando viceversa a un vero e proprio codice iconico che esprime una continua tensione verso il divino. Alcune ricerche fanno risalire la definizione iconografica dei santi a una gerarchizzazione di tipo aristotelico definitio fit per genus proximum et differentiam specificam. I santi sono collocati in grandi categorie definite dall'abbigliamento. Quest'ultimo è sontuoso per i santi combattenti, ornato da croci per i vescovi e per i 'padri della chiesa', dimesso per tutti gli altri. All'interno di queste grandi categorie il 'santo' è definito dagli attributi del volto: colore della pelle, barba, capelli. I santi senza barba sono in genere molto giovani, inoltre la barba può essere di diversi colori: bianca, rossa o scura; lunga o corta, separata a livello del mento. I capelli hanno lo stesso colore della barba e si differenziano in base alla stempiatura o all'eventuale tonsura. Nell'iconografia bizantina, a differenza di quanto avverrà in quella latina, i santi non sono identificabili dai loro attributi, fanno eccezione san Pietro e pochi altri. San Nicola di Myra, il caso studio di questa ricerca, ha due attributi ricorrenti, l'omophorion e il volumen, che ricordano i suoi miracoli (fig. 4).

La fruizione delle pitture rupestri, e non, può essere complessa; per questo motivo in alcuni siti si è ricorsi al video mapping, proiezione in situ d'immagini restaurate [9]. Per dare rigore a queste tecniche occorre elaborare un protocollo scientifico per colmare le lacune degli affreschi.

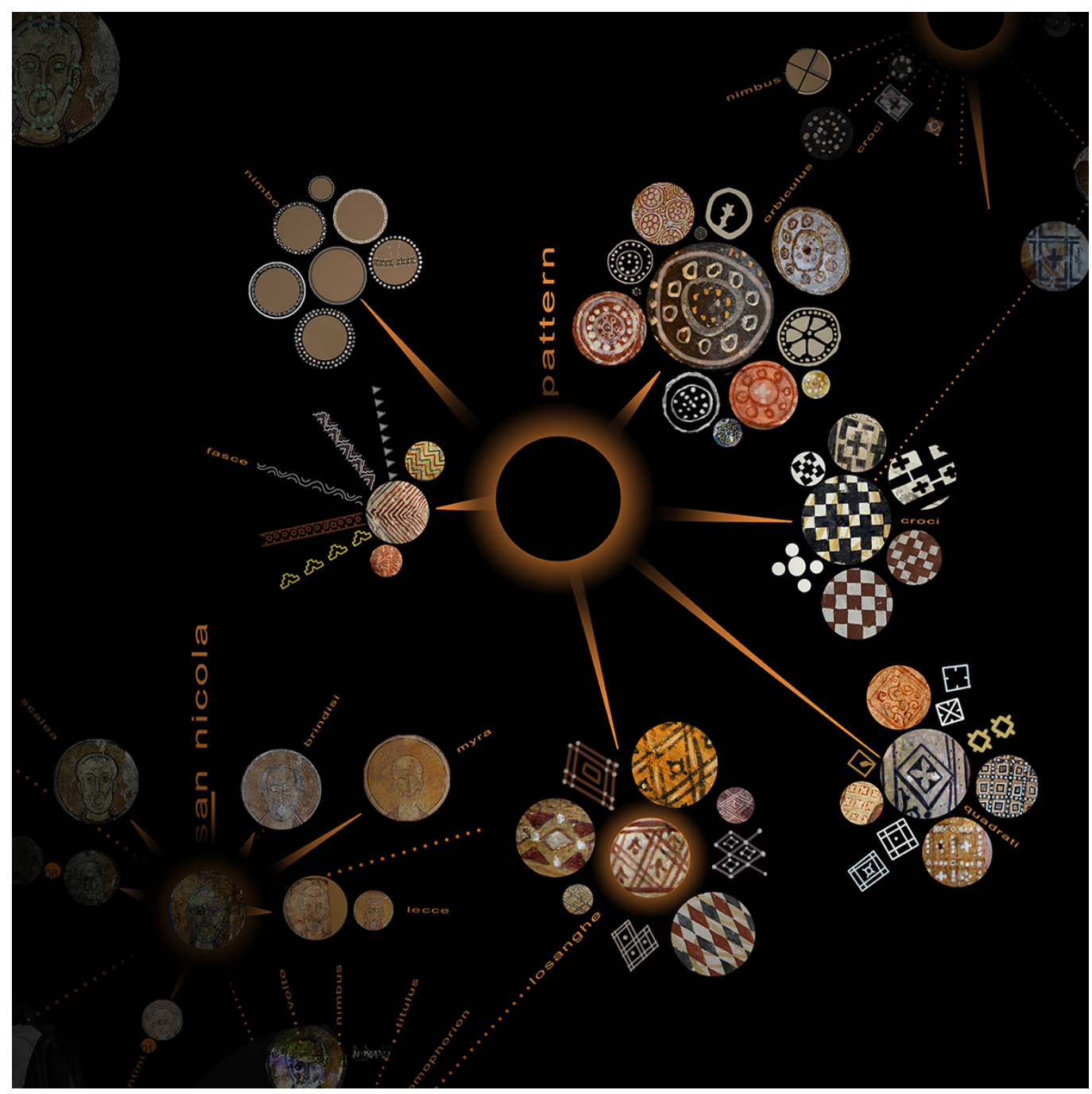


Maronidis, Voutounos e Lanitis hanno elaborato una procedura basata su uno studio statistico-matematico [10] dei volti presenti negli affreschi bizantini. I volti, in questo caso studio della Vergine, sono stati analizzati con apponendo numerosi target sugli elementi caratterizzanti: sopracciglia, occhi, labbra, mento. La grande quantità di dati immagazzinati fa sì che sofisticati algoritmi siano in grado di generare una ricostruzione delle lacune compatibile con il volto in oggetto.

II restauro virtuale è funzionale a diversi obiettivi: preservazione del bene, analisi e confronto incrociato, creazione di musei virtuali. In questa ricerca il volto di San Nicola, presente in moltissime delle chiese analizzate, è stato discretizzato attraverso 35 punti, le diverse rappresentazioni sono state messe a confronto dopo aver uniformato la distanza fra le pupille. Sovrapponendo i target possiamo notare che c'è una certa omogeneità fra il volto di San Nicola di Mottola e quelli provenienti dalle limitrofe chiese rupestri del leccese o dalla Iontana Myra, attuale Derme nella provincia turca di Antalya. I target sembrano combaciare perfettamente se si eccettua la dimensione della barba lungo il mento (fig. 5). Un'altra tipologia di volto sembra emergere mettendo a confronto il volto di San Nicola presente nella chiesa del Crocifisso di Lentini, con l'omonima chiesa di Ugento, Lecce o con quelli della chiesa di san Biagio nel brindisino.

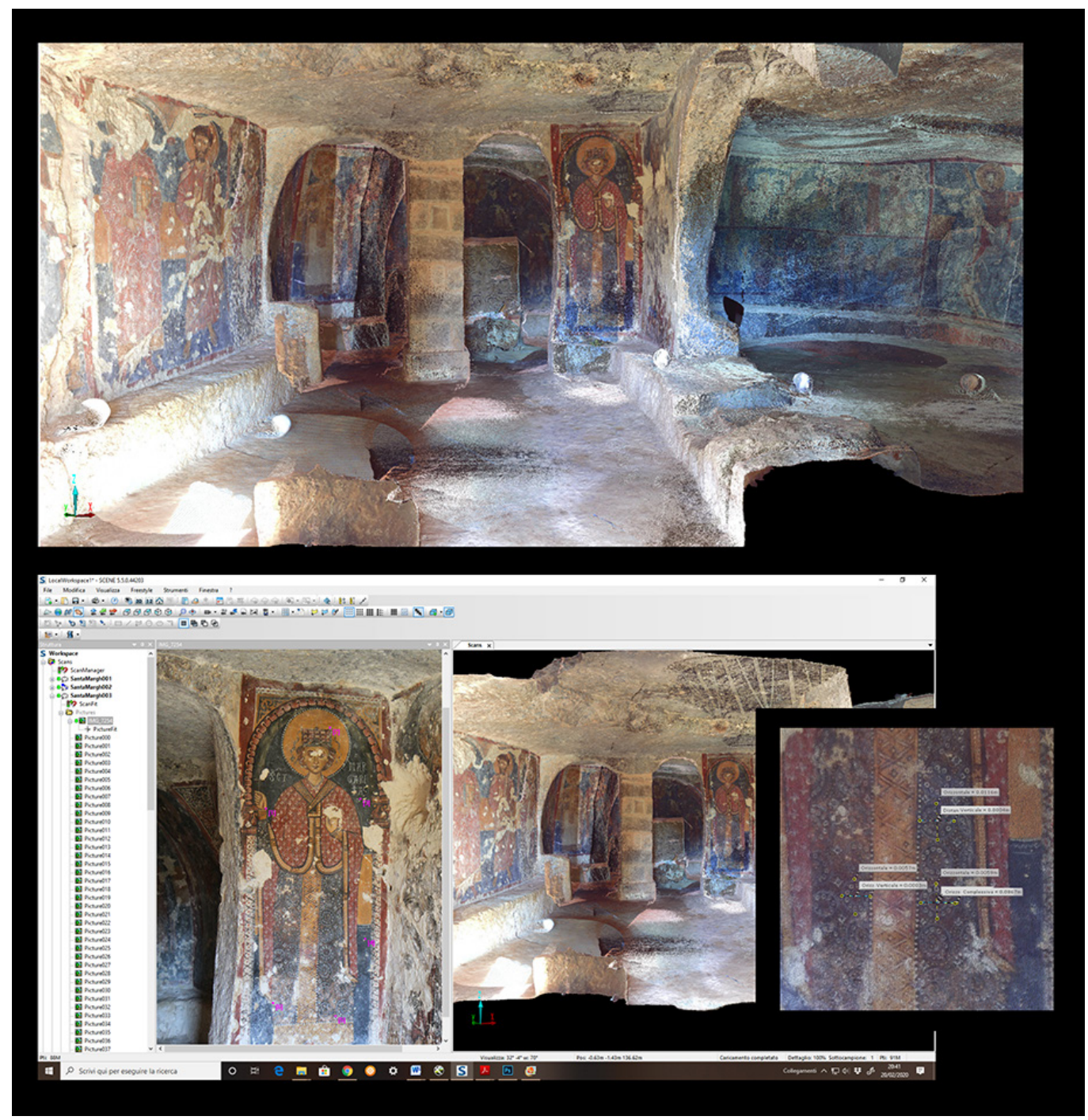




\section{Pattern geometrici}

Un discorso a parte meritano le decorazioni aniconiche, geometriche che più spesso ornano le vesti dei santi, il maphorion della Vergine, mentre in altri casi formano ricche cornici intorno alle scene rappresentate (fig. 6-8). Gli storici non hanno individuato, con precisione, i riferimenti formali e culturali che sono alla base dell'uso dei pattern geometrici. Infatti, sono molti i riferimenti e le cause probabili: le decorazioni settili dei pavimenti siriani; la contiguità culturale e territoriale con le popolazioni nomadi del vicino oriente; la fase aniconica derivata guerra iconoclasta e, più ancora, la tendenza di tutta l'arte bizantina alla bidimensionalità. Quest'ultima, infatti, genera il necessario distacco dalla mimesi del reale e sottolinea la tensione verso il divino.

Recentemente gli studi sull'arte bizantina, "rinunciando alla ricerca dei significati, [... ] hanno sperimentato interessanti aperture verso il dato formale, favorendo l'analisi dei dettagli ornamentali, in grado, più di ogni altra cosa, di svelare la natura delle reciproche mutuazioni nei singoli manufatti" $[\mathrm{II}]$.

Prendendo spunto da queste ricerche si è pensato di operare una catalogazione e una tipizzazione dei dettagli ornamentali basata unicamente sul dato formale. Le categorie individuate sono: orbiculi, losanghe, quadrati, fasce, croci, nimbi. Ogni elemento è stato ordinato dal più semplice al più complesso. La combinazione di pochi elementi può, infatti, generare una molteplicità decori.

Gli orbiculi, ad esempio, sono decorazioni basate sulla circonferenza. Simulano i decori riportati sulle sete bizantine di derivazione sasanide. II decoro più semplice è composto di sei o sette 'perle', piccoli punti bianchi disposti intorno ad un centro. In alcuni casi il centro è rappresentato da una circonferenza, e i punti possono essere pieni o vuoti, circondati da uno o più circonferenze. La combinazione dello stesso elemento, una circonferenza, genera decori differenti. Gli orbiculi decorano spesso le vesti delle sante, santa Margherita a Mottola, o dei vescovi. Rendono la rappresentazione del maphorion o del sakkos più ricca e interessante.

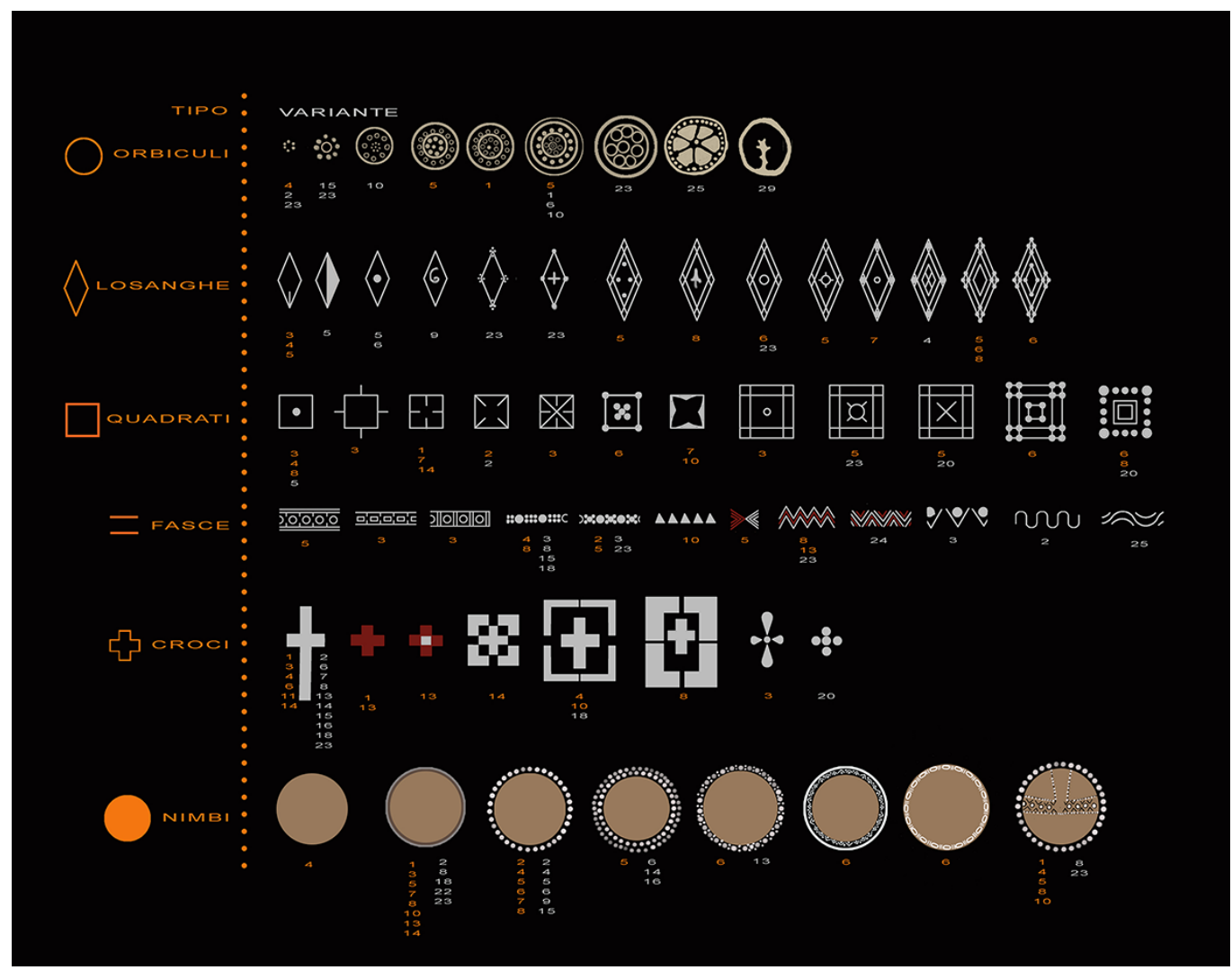


Le losanghe presentano due grandi categorie: quelle con una sola linea di contorno e quelle doppie o triple. Le prime si differenziano in base al contenuto: un piccolo cerchio, una spirale, un piccolo segno che rappresenta il giglio. Fra quelli con la linea di contorno semplice troviamo il rafforzamento degli spigoli con punti di colore chiaro, perle. Le losanghe con bordo doppio o triplo ripetono lo schema compositivo delle prime: presentano elementi nella superficie interna o perle che rimarcano gli spigoli, disegnando delle croci. I quadrati, spesso disposti in obliquo, presentano decorazioni che riguardano la mezzeria dei lati, trattini verso l'esterno o l'interno, o segni che sottolineano le diagonali. Alcuni hanno all'interno il motivo a quinconce: quattro perle disposte ai vertici di un quadrato e una al centro. I quadrati con bordo doppio hanno al loro interno: circonferenze, piccole croci o serie concentriche di quadrati con i vertici decorati da perle.

Le fasce sono composte di disegni lineari, una successione di quadrati con piccole circonferenze centrali, o da motivi a zig-zag. Altre fasce sono composte di perle disposte a quinconce o a serie da sei. In fine troviamo triangoli pieni o linee sinuose.

Negli affreschi bizantini le croci, simbolo della fede cristiana, assumono una connotazione decorativa. Le croci latine, con bracci asimmetrici, marcano l'omophorion, una stola che designa il vescovo come il buon pastore. Le croci greche ricoprono i sakkos, polistavrion, dei santi vescovi o dei padri della chiesa d'oriente; alcune sono semplici composte da cinque moduli quadrati uguali altre sono racchiuse da cornici aperte che formano, nella ripetizione del disegno, altre croci più grandi. Più rare sono quelle con perle o forme a goccia.

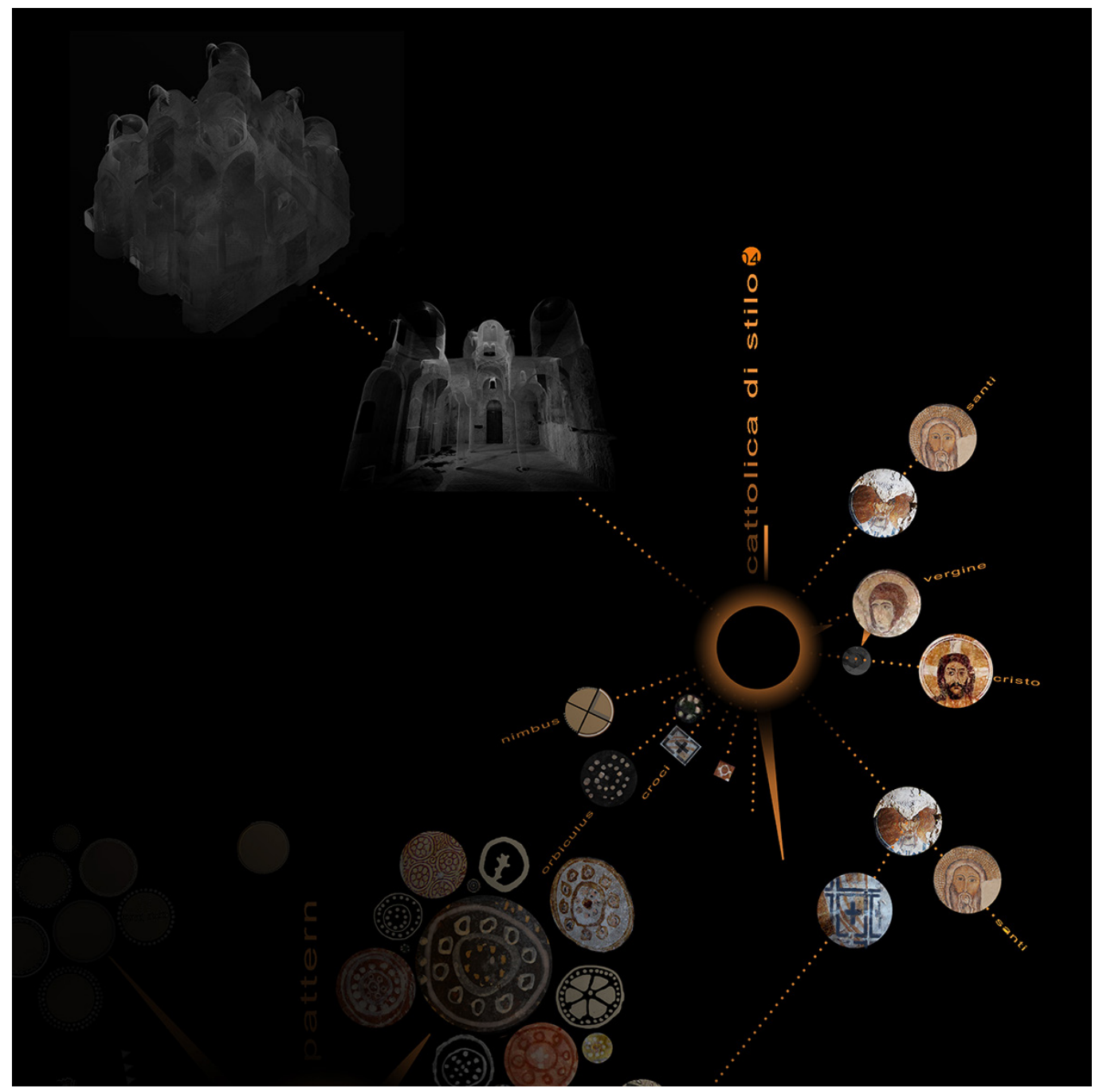




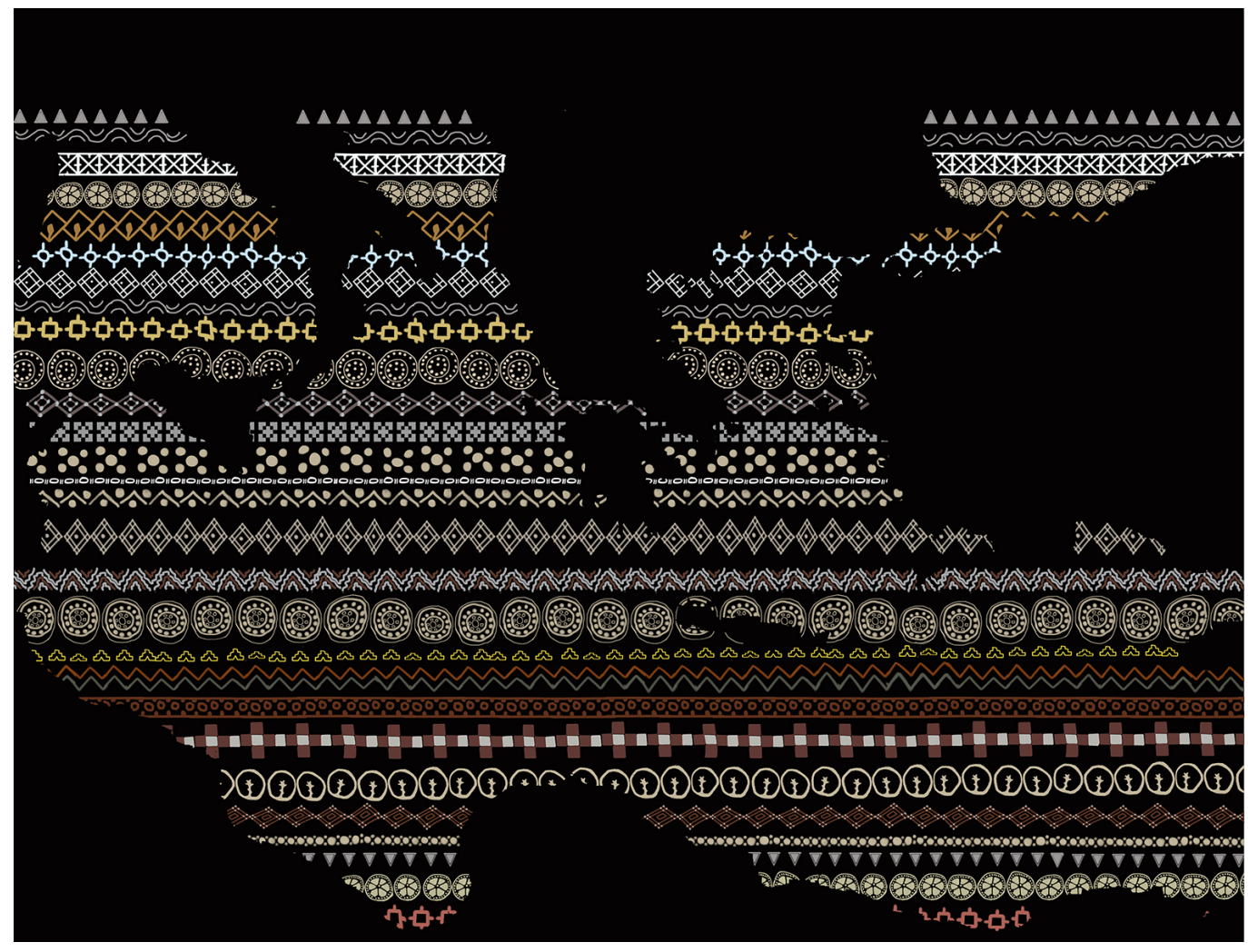

Infine troviamo i nimbi, dai più semplici: senza neanche il bordo a marcare il contorno fra aureola e sfondo; ai più complessi e ricchi: nimbi perlati con uno o due giri di perle. I bordi dei nimbi presentano in alcuni casi decori a fascia con triangoli alternati a perle o con ellissi alternate a un doppio trattino. II nimbo crociato è solitamente dedicato al Cristo, la croce può essere semplice o decorata con le stesse modalità del bordo.
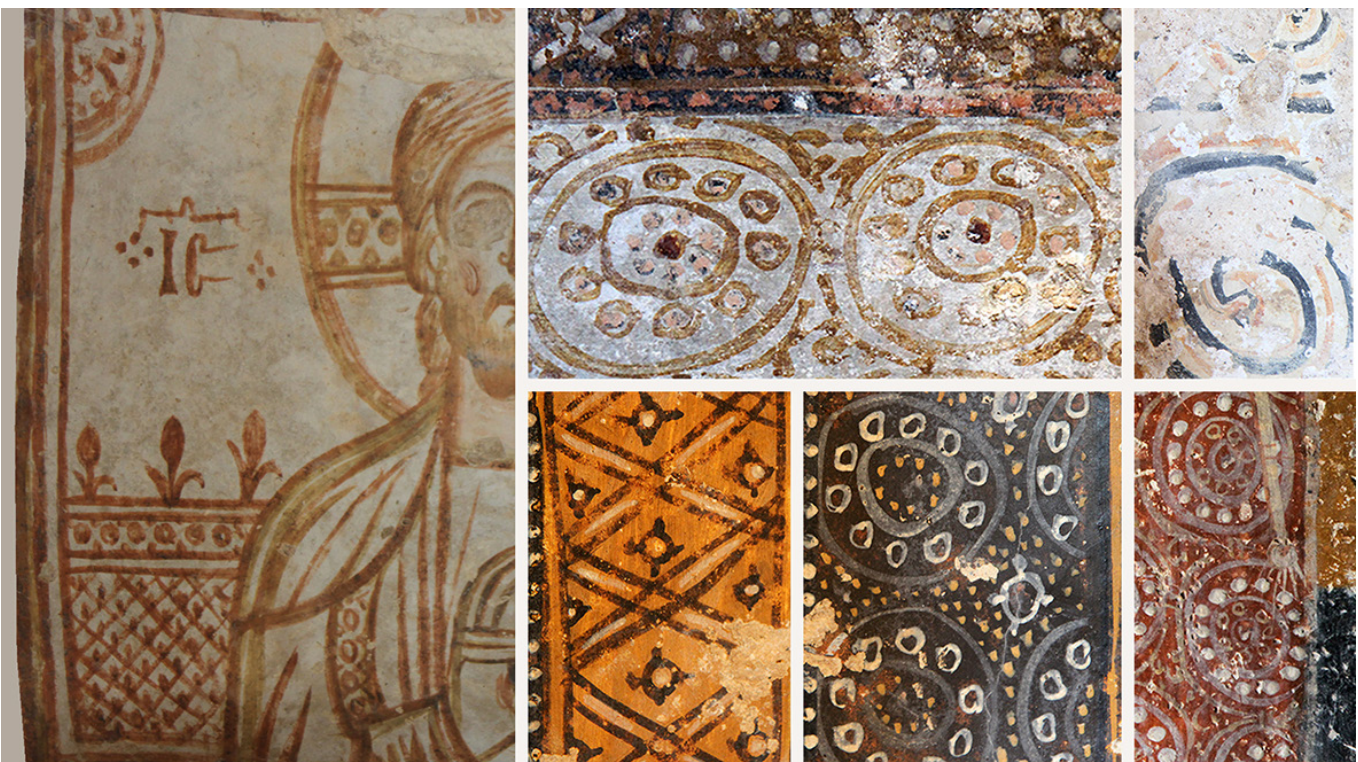


\section{Conclusioni}

I pattern di questa ricerca sono come i tessuti bizantini preziosi, densi, fragili. Sono fatti di polvere, calce e pigmenti: nonostante la loro apparente staticità e rigidezza si allungano nello spazio e nel tempo per evocare assonanze, illuminare connessioni, e intessere relazioni di forme e colori in un intreccio che forse non riusciremo mai a dipanare, ma nel quale è bello perdersi (fig. 8).

\section{Note}

[I] Lo studio è parte di una ricerca più ampia dal titolo Fra lonio ed Egeo condotta con Daniele Colistra e Domenico Mediati, che ha visto il rilievo di moltissimi edifici sacri di epoca bizantina.

[2] Si veda: Grabar 1964, p. 14 e pp. I50- 152: "lo stile di tutte queste pitture [...] si riconnette per mille fili alle opere più antiche della Cappadocia".

[3] Nelle chiese di rito bizantino, tanto quelle fuori terra che quelle scavate, vi è una stretta correlazione fra lo spazio e la sequenza d'immagini. L'ordine e la collocazione delle immagini sacre, che prendono un assetto definito intorno al XII secolo, sono pensati per ribadire che la chiesa materiale è figura di quella spirituale. Si veda: Florenskij 1922. Fanno parte delle rappresentazioni canoniche: il Cristo Pantocratore o in Déesis, spesso collocato nel catino absidale; la Vergine, Odigitria Glycophilousa (della tenerezza) o Kyriotissa (regina) appare nelle immediate vicinanze dell'abside o in parti assimilabili a una rozza iconostasi in pietra. Nelle chiese rilevate troviamo spesso la figura dell'arcangelo Gabriele e di San Michele che scaccia il drago. Inoltre la rappresentazione dei padri della chiesa orientale, San Basilio Magno, San Gregorio Nazianzeno, San Giovanni Crisostomo, lascia presupporre un collegamento con le comunità monastiche della Cappadocia.

[4] si veda: Grabar 1964, pp. 27, 28.

[5] I pattern geometrici spesso sono utilizzati per decorare le vesti dei santi, per identificarli, o per creare suddivisione all'interno delle superfici pittoriche. La cultura visuale bizantina, come sappiamo, travalicò i confini dell'impero e s'impose attraverso la religione e il commercio di beni di lusso. Fra questi ultimi il più ricercato era la seta. Complessi accordi commerciali davano all'impero bizantino il primato sul suo commercio. Le preziose sete riprendono motivi decorativi persiani e sasanidi e sono capaci di veicolare, in profondità, il sincretismo iconografico bizantino.

[6] Di seguito l'elenco dei rilievi e dei riferimenti ordinati da occidente a oriente.

Rilievi: 01_Chiesa del Crocifisso_Lentini, Siracusa; 02_Chiesa Madreᄀ_Savoca Messina; 03_Chiesa di S.Adriano_San Demetrio Corone_Cosenza; 04_Cattolica_Stilo_Reggio Calabria; 05_Santa Margherita_Mottola_Taranto; 06_San Nicola_ Mottola_Taranto; 07_San Gregorio_Mottola_Taranto; 08_San Lorenzo_Fasano_Brindisi; 09_San Giovanni_Fasano_Brindisi; 10 Eremo S. Anargyri_Agia_Larissa; I I_Eremo S. Pantaleimon_Melivoia_Larissa; I2_Monastero S. Pantaleimon_Agia_Larissa; 13 Chiesa della Vergine Kato Polidendri_Larissa; 14 Chiesa della Vergine Velika Lärissa.

Riferimenti: I_Abbazia di Santa Croce_Polizzi Generosa_Palermo; 2_Chiesa dello Spedale_Scalea_Cosenza; 3_Chiesa di San Zaccaria_Caulonia_Reggio Calabria; 4_Santa Lucia_Melfi_Potenza; 5_Chiesa della Panaghia_Rossano Calabro_Cosenza; 6_Santa Lucia alle Malve_Matera; 7_San Nicola dei Greci_ Matera; 8_Chiesa San Biagio a San Vito dei Normanni_Brindisi; 9 Chiesa Santa Croce Massafra Taranto; 10 Chiesa rupestre Madonna della Buona Nuova Massafra Taranto; I Chiesa di Santa Barbara_Ginosa_Taranto; I2_Chiesa di San Leonardo_Ginosa_Taranto; I3_Chiesa di San Vito_Gravina in Puglia_ Lecce; I4_Cripta del Crocifisso_Ugento_Lecce; I5_Chiesa rupestre delle Sante Marina e Cristina_Carpignano_Lecce; I6_ Chiesa rupestre di Santa Maria degli Angeli_Poggiardo_Lecce; I7_San Giorgio_Kurbinovo_Macedonia; I8_Chiesa Boyana_ Sophia; 19 Chiesa della Koimesis Asinou Cipro; 20 Hagia Sophia Istanbul; 2 I S. Salvatore in Chora Istanbul: 22 Chiesa san Nicola Derme Antalia; 23 Karanlik Kilise Goreme Cappadocia; 24 Yilannli Kilise Cappadocia; 25 Kokar Kilise Cappadocia; 26_Purenlì Seki Kilise_Cappadocia; 27_Bahattin Samanligi Kilise_Cappadocia; 28_Sumbullu Kilise_Cappadocia; 29_Direkli Kilise_Cappadocia.

[7] Nella chiesa rupestre di San Nicola troviamo inoltre le rappresentazioni della Vergine,Theotókos Odigitria (che mostra la

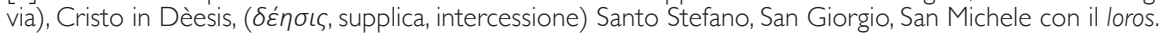

[8] "Pursuing the 'representation' rather than the 'imitation', Byzantine artists used a limited range of forms. Within these stylistic norms they changed the physical appearance by modelling the shape of the head and the outline of the cheeks. They used lighter or darker pioments to achieve different skin tones. A wider colour and variety of form was possible in depicting hair and beard They could be dark, red or white, long or short, whereas the absence of beard and moustache was meant to suggest young age. This method allowed the creation of a very limited number of face-types. This is confirmed by monotonous descriptions in iconographic manuals and eikonismos collections" [Grotowski 20 I0, pp. 137, I38].

[9] Lama D’Antico, Fasano. Restauro virtuale tramite videomapping a cura di Giuseppe Donvito, responsabile del Parco,

\section{Riferimenti bibliografici}

Beckwith John (1967). L'arte di Costantinopoli, una introduzione all'arte bizantina (330-/453). Torino: Einaudi (I Ed. The art of Constantinople, An Introduction to Byzantine Art. London: Phaidon Press, 1961).

Florenskij Pavel A. (2002). Le porte regali. Saggio sull'icona, a cura di E. Zolla, Milano: Adelphi.

Fonseca Cosimo Damiano (1970). Civiltà rupestre in terra jonica. Milano: Carlo Bestetti Edizioni.

Grabar André (1964). Bisanzio. (traduzione Silvia De Cesaris). Milano: Il Saggiatore. (I Ed. Byzance. Baden: Holle Verlang, 1964).

Grotowski Piotr Ł. (20 I0). Defining the Byzantine Saint, Creating a Message in Orthodox Art in Towards Rewriting? New Approaches to Byzantine Archaeology and Art. Warsaw: Edited by P. Ł. Grotowski and S. Skrzyniarz. 
Innemée Karel C. (1992). Ecclesiastical Dress in the Medieval Near East. Leiden: Brill.

Lentini Pasquale (1988). Il fenomeno della civiltà rupestre nel territorio di Mottola. Galatina: Congedo.

Maronidis A., Voutounos C., Lanitis A. (20I4). Designing and Evaluating an Expert System for Restoring Damaged Byzantine Icons. In Multimedia Tools and Applications, June 2014. New York: Springer Science+Business Media.

Medea Alba (20।4). Gli affreschi delle cripte eremitiche pugliesi. Lecce: Capone.

Scalzo Marcello (2002). Sul rilievo di architetture rupestri. Firenze-Massafra: Archeogruppo.

Settis Salvatore (2005). Iconografia dell'arte italiana I 100- I 500: una linea. Torino: Einaudi.

Thierry N., Hierry M. (1963). Églises rupestres de Cappadoce, région du Hasan Dagi. Paris: Librairie Klincksieck.

Autore

Marinella Arena, Università degli Studi Mediterranea di Reggio Calabria, marinella.arena@unirc.it

Per citare questo capitolo: Arena Marinella (2020). Connessioni geometriche: per una catalogazione fantastica dei pattern bizantini/Geometrical Connections: for a 'fantastic' cataloguing of Byzantine patterns. In Arena A., Arena M., Brandolino R.G., Colistra D., Ginex G., Mediati D., Nucifora S., Raffa P. (a cura di). Connettere. Un disegno per annodare e tessere. Atti del $42^{\circ}$ Convegno Internazionale dei Docenti delle Discipline della Rappresentazione/Connecting. Drawing for weaving relationships. Proceedings of the 42th International Conference of Representation Disciplines Teachers Milano: FrancoAngeli, pp. 2931 -2954. 


\section{Geometrical Connections: for a 'Fantastic' Cataloguing of Byzantine Patterns}

Marinella Arena

\section{Abstract}

The study focuses on the iconography of the Byzantine churches in the Mediterranean and is part of a larger research project, dedicated to oriental-based religious architecture built between the ninth and sixteenth centuries. The research methodology is based on: instrumental and photographic survey; analysis and cataloguing of iconographic and decorative apparatus; visual communication of data and connections traced.

Keywords

Mediterranean, pattern geometrics, Byzantine iconography, cataloguing.

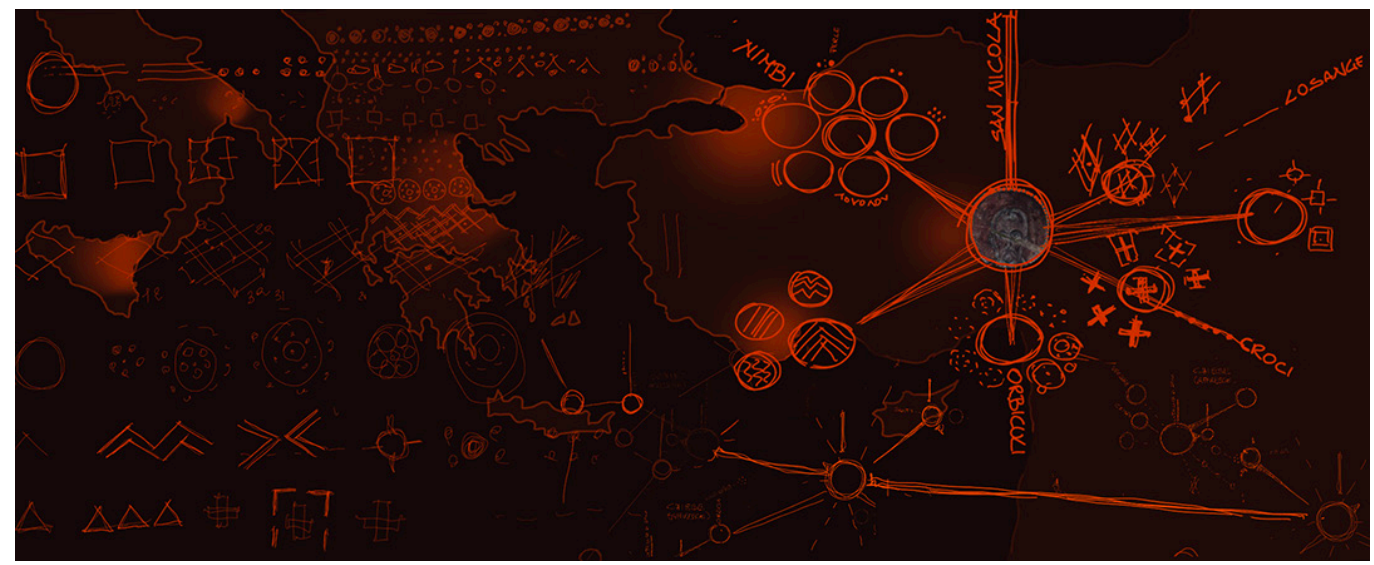




\section{Introduction}

The connections, in the Mediterranean Sea, are straight threads between ghost cities and vital ports, between aulic buildings and vernacular details. Threads drawing a changing fabric, complex and three-dimensional, which reconnect new warps to old wefts. The light silk fibres, coloured with kermes, indigo and Pernambuco, overwhelm the old ones when the empire of Byzantium overcomes the Aegean Sea limit and goes toward the whole Mediterranean Sea.They are the sign that a new cultural era is coming.

This research starts from the wefts made by formal and esthetical links which the byzantine culture spread towards the Mediterranean Sea, especially between the Ionian and the Aegean Sea, and tries to implement the dissemination, and the documentation, of the iconographic apparatus of the rocky churches and the sub divo ones [I]. The byzantine churches were completely painted with fresco, so the complexity and the multiplicity of the signs which marked the holy space created a weft rich in links between: pagan and sacred; theological and stylistic; geographical and cultural. The threads, which in the past were a connection between sign and meaning, are now worn out, sometimes broken, by the passage of time and the disuse.

The research strategy is centred on some aspects of the sacred iconography and speculates about an 'alternative' (non-conventional) classification of the geometrical decorations, capable joining the threads which were broken. The study, with a ludic approach to the communication and valorisation, on one hand underline the visual connections of the iconographic apparatus of byzantine architectures, and on the other hand rebuild, through a typological abacus, an 'artistic geography'[2] of the geometrical motifs.

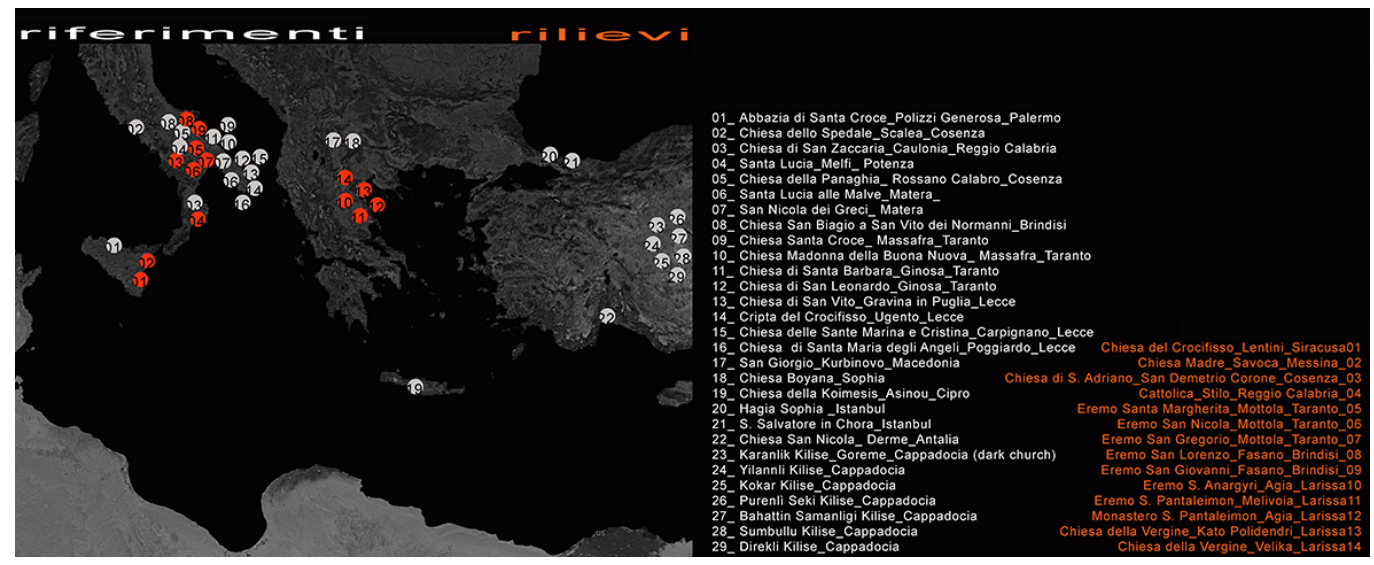

The byzantine churches, which had preserved their architectural structure and their iconographic apparatus, are few. In fact, the passage from the Oriental rite to the Latin one often meant the alteration or the complete destruction of the buildings. On the contrary, where the rite remains oriental, for example in Greece, the multiple modifications to adapt the space to the modern necessities of religious worship interrupted the continuity and the originality of the architectonical language.

The holy rocky churches, the core of this research, are the ones that have been saved better, due to the substantial abandon, the original shape and the iconographic apparatus [3]. Most of the frescoes show large gaps and detachments caused by carelessness and by deliberate damage. The fruition of the frescoes, as the comprehension, is now difficult and incomplete due to objective and cultural reasons. 
The iconographic byzantine art is such a complex phenomenon that one of its maximum scholars said: "at the actual stadium of our knowledge we are not able to establish links between the saved pieces of art and the social structure or the byzantine geography [...] some general facts reaffirm this pessimistic attitude: the systemic anonymity of the byzantine pieces of art, the extreme lack of the written sources, caused by the disruption of almost all the archives; in the end the insufficient differentiation between the pieces of art" [4].

How it is possible to think about cataloguing when everything is so uncertain?

The aim of this research, focused in the drawing field, is to take a cue from the surveys to layout, showing, some of those treads which link together stylemes, details and sacred iconographies. The classification is, for this reason, 'non-conventional' and partial. In fact the classification, still supported by historical and documental criteria, links buildings, images and ornaments with morphological, proportional and typological criteria.

Some representation of saints and some kind of geometrical ornaments, as exempla of the analysis and description process, have been analysed. The geometrical motifs are a distinctive feature of byzantine iconography; they deserve to be studied in depth in order to achieve a morphological systematization [5].

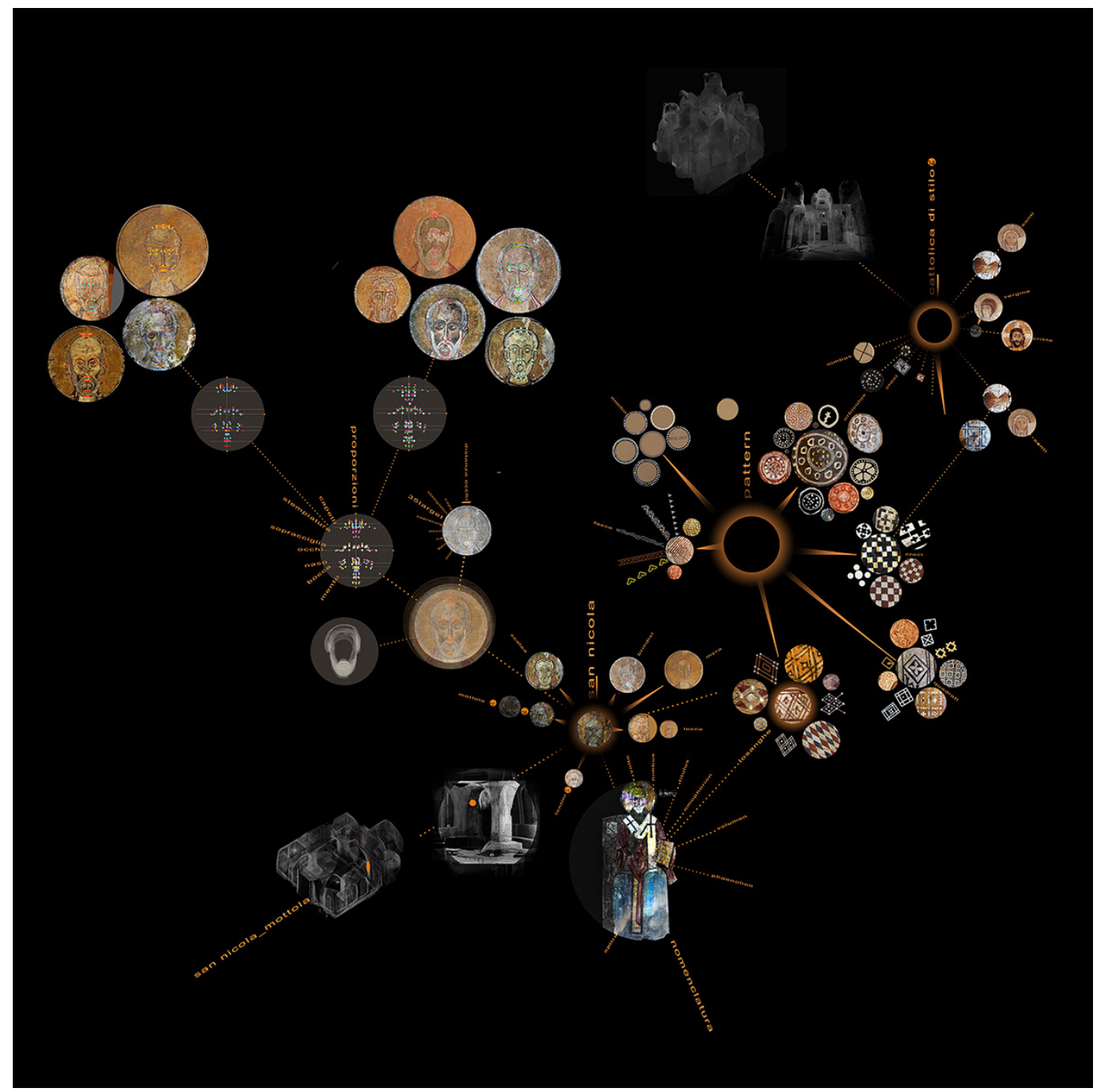




\section{Research Methodology}

The research strategy has many levels: finding the more pertinent exempla to the selected issue (fig. I); instrumental and direct survey; analyses and cataloguing of the artefacts and the design of a non-conventional cataloguing useful for the valorisation and communication of the cultural heritage [6].

The churches, useful for this study, have a clear iconographic apparatus; dating back to the IX and the XIV century and belonging to the ancient Thema of Sikelia, (which, after the Arab conquest of Sicily, became Thema of Calabria), to the Thema of Langobardia (the current Puglia), and to the Thema of Hellas, in Thessaly.

The instrumental survey together with the photographic one, are a good start for the database which illustrates the geographical placement of the sacred iconography.

The first phase of the research shows a graphic visualization of the interconnections between the pictures of the main Saints, it shows also the localization and the typologies of the recurrent geometric motif of the surveyed churches (fig. 2).

The second phase of the research (fig. 7) elaborates a typological and geometric cataloguing useful for finding the shape and the real proportions of the analysed patterns. In this part of the research the laser scans have been implemented by several HD (high dimension) images, so patterns shape and dimension will be better analysed.

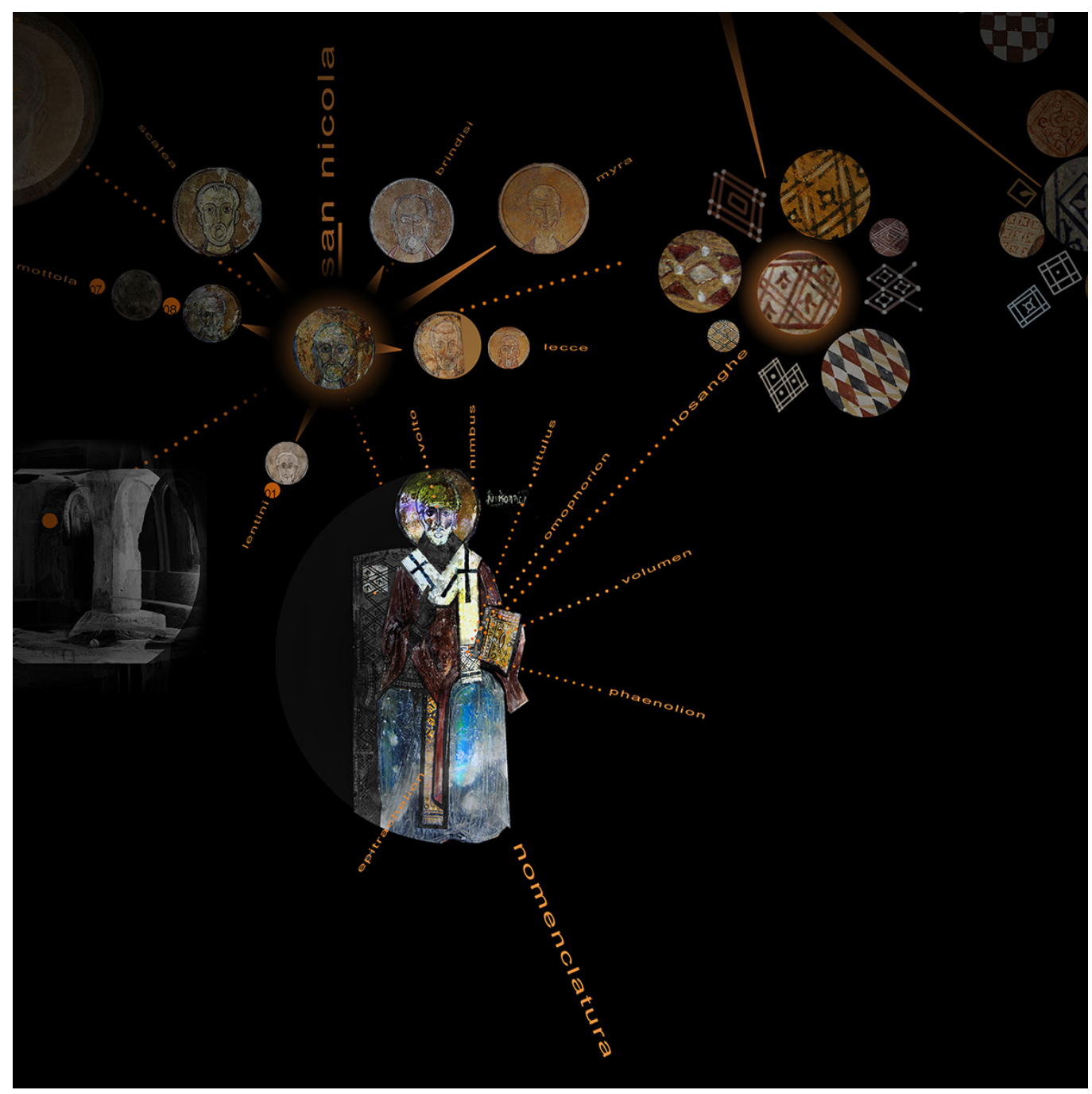




\section{Connections}

The connections which link together the surveyed churches and the iconographic representations are multiple and graphic (fig. 2 ) the study case is the iconography of Saint Nicholas of Myra, very common in the south of Italy and linked to the country of origin, the ancient Thema di Kibyrrhaioton, the current Derme.

The graphic design of this research uses a unique flow of images which permits connecting the iconography of the saint easily to: the homonym church [7]; the related nomenclature; the other representations of the same Saint and to the decorative apparatus which ornate his figure and his robes. From each element a new connection could spring up. Starting from the robe motif of the saint, for example, it is possible to join the area of geometric pattern. One of these is the cruciform motif which decorates the bishop's robe, polistavrion. St. John Chrysostom, one of the fathers of the oriental church, depicted in the Cattolica of Stilo (fig. 3), has the cruciform motif on his robe.

One of the research objectives is to simplify the identification of the saint through a direct, intuitive and visual approach. In fact it is not easy [8] to identify the Byzantine saints due to the damage suffered, the frescoes often lack parts of the face of the saint, and to the homogeneity and abstraction of the representations. The stereotyped repetition of some

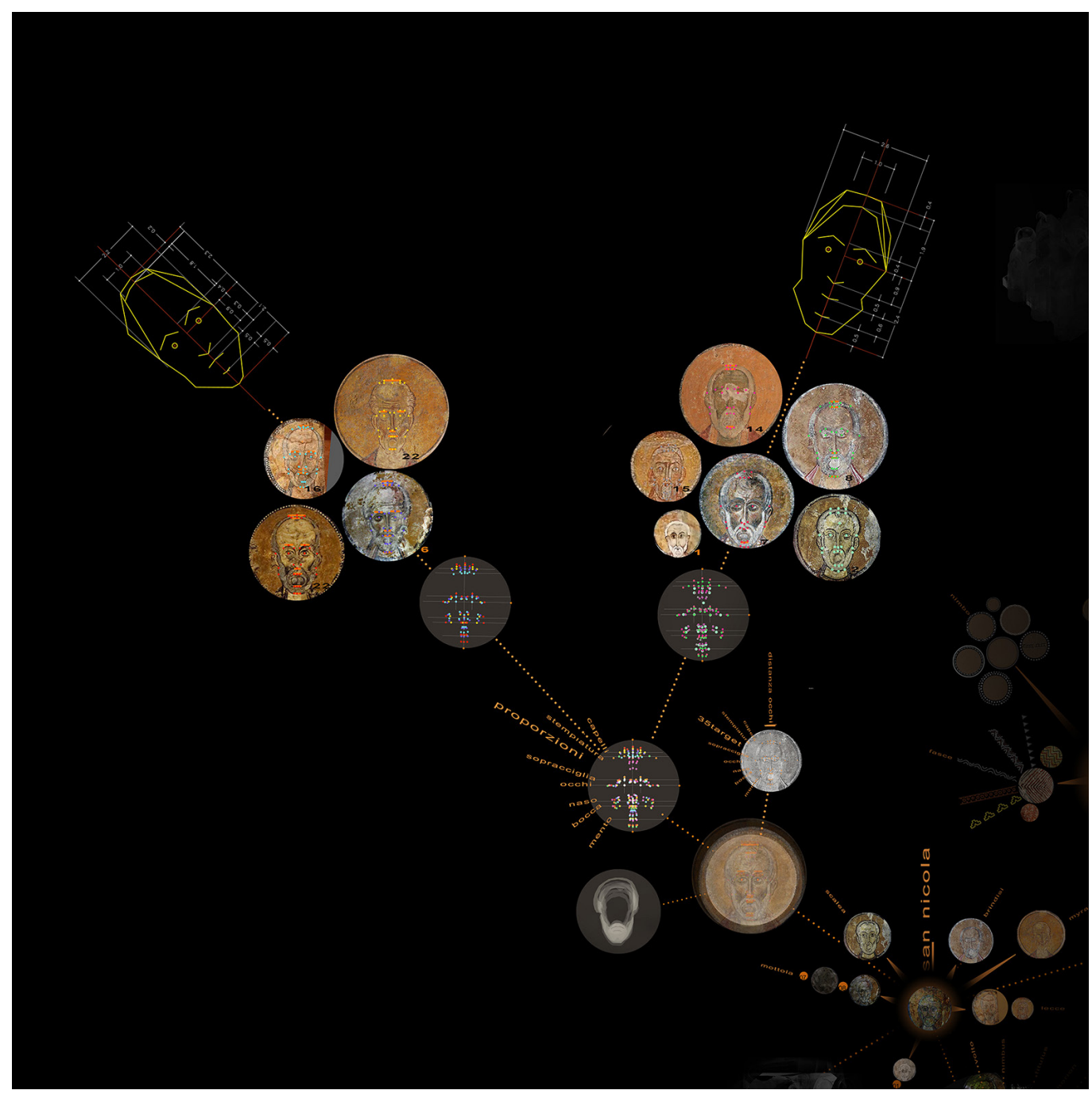


aspects related to the iconography of the saints, of Christ, or of the Madonna, is useful to separate the sacred images from the mimetic representation of the reality. This kind of image elaborates a real iconic code which shows the continuous tension toward the divine. Some studies trace the iconographic definition of the saint to an Aristotelian hierarchy: definitio fit per genus proximum et differentiam specificam.

The saints are placed in large categories which are defined by the vestments. These latter are sumptuous for the fighting saints, decorated by many crosses for the bishops and the 'fathers of the church', very simple for the others. Inside these categories the 'saints' are identified by the face attributes: the colour of the skin, beard, and hair.The saints without a beard are the youngest ones; in addition the beard could be of various colours: white, red, dark; long or short, cut in two parts on the chin. The hair has the same colour us the beard and they differ in the hairline or in the tonsure. In the Byzantine iconography, different from what develop in the Latin worship, the saints are not recognizable by their attributes: Saint Peter is one of the few exceptions. Saint Nicholas of Myra, the case study of this research, has two recurrent attributes: the omophorion and the volumen, which remember the miracles of the saint (fig. 4).

The fruition of the rock frescoes could be complex; for this reason in some cases a video-mapping, projection in situ of the restored images, has been done [9]. To ensure scientific

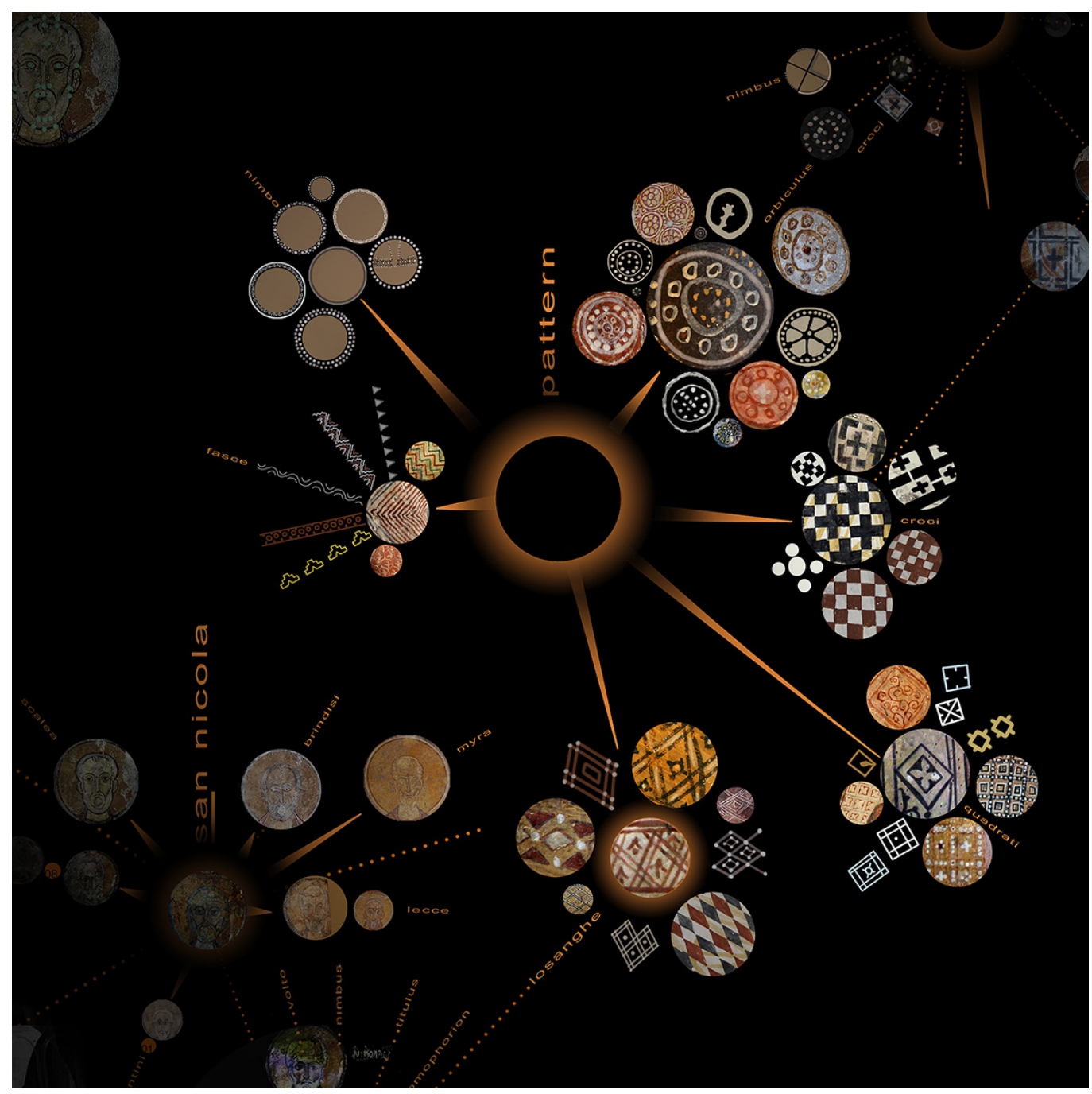


rigor to these techniques it is important to elaborate a specific protocol to fill the missing parts of the frescoes. Maronidis, Voutounos and Lanitis, for example, have elaborated a procedure, based on a statistic-mathematical [I0] study, on the faces present in the Byzantine frescoes. The visages of the Virgin Mary, have been analysed by placing many targets on the facial features: eyebrows, eyes, lips, chin. The sophisticated algorithms, using a vast quantity of data, have been able to generate a reconstruction of the missing parts.

The virtual restoration is practical for many reasons: preservation of the assets, analyses and cross comparisons, creation of virtual museums. In this research the face of Saint Nicholas, present in many analysed churches, has been simplified by way of 35 points; the different representations have been compared after matching the distance between the eye pupils. Overlapping the target we notice that there is certain uniformity between the shape of the face of Saint Nicholas of Mottola and the others originating from the near rocky churches of Lecce or coming from the distant ancient Myra, now Derme, in the Turkish province of Antalya. The targets seem to overlap perfectly, if we exclude the beard on the chin only (fig. 5). Another typology of face seems to emerge confronting the face of Saint Nicholas, Church of Crocifisso in Lentini, with the homonym church in Ugento, Lecce, or with another visage painted in the church of Saint Biagio in Brindisi.

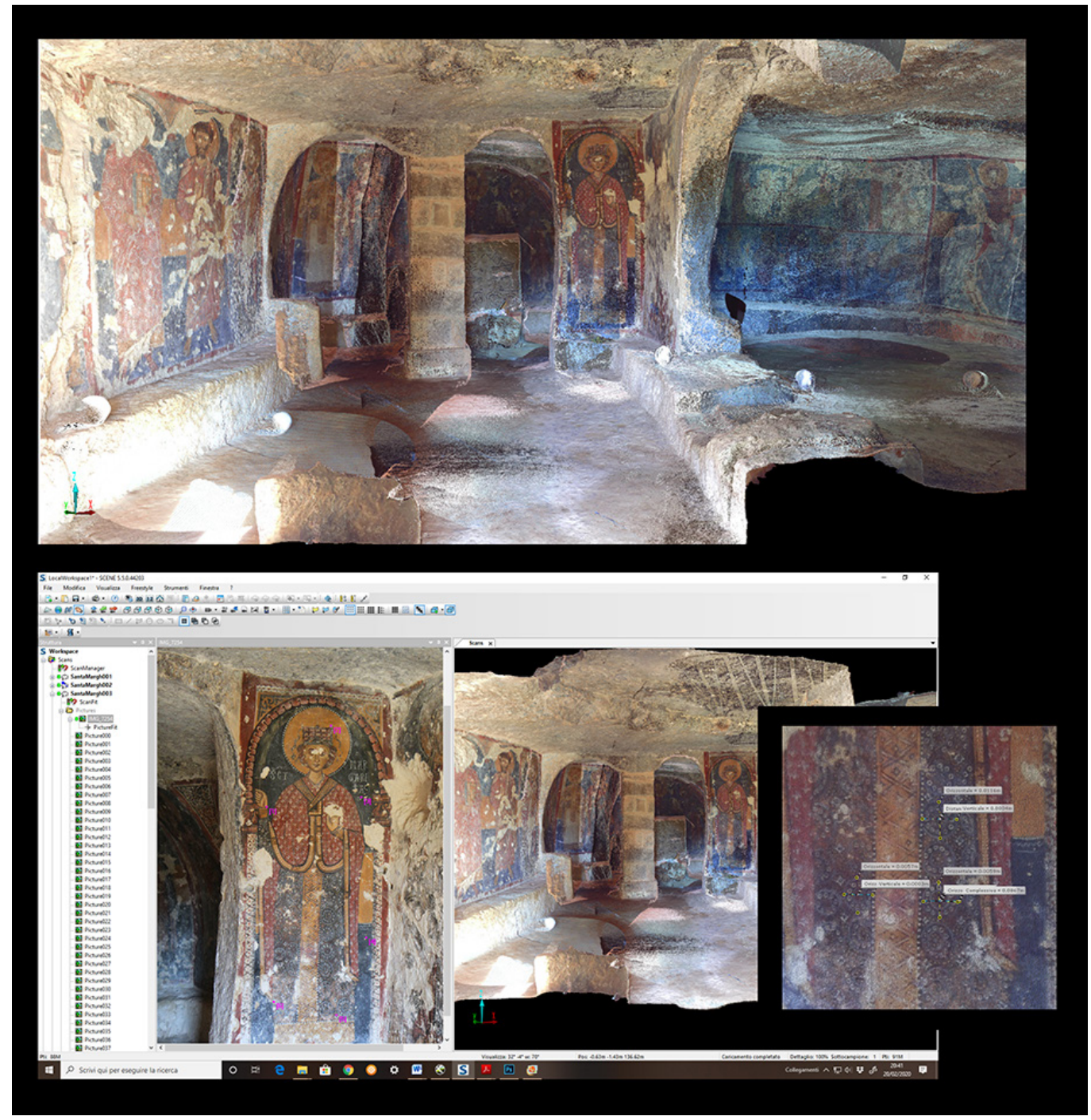




\section{Geometric Patterns}

The aniconic decorations require a specific study. The geometric ones adorn the saints' vestments, such as the maphorion of the Virgin, while others form the rich frames that surround the representations of the frescoes (fig. 6-8). Historians have not found, precisely, the formal and cultural links which are the basis of the geometrical patterns. In fact there are many references and causes likely: the opus sectile of the Syrian floors; the territorial and cultural vicinity with the nomadic population of the near orient; the aniconism, coming from the iconoclastic fights, and more than others the tendency of the Byzantine art to two-dimensionality. The latter creates the required detachment from the reality mimesis and underlines the tension toward the divine.

Recently the studies about the Byzantine art "giving up the search for meanings [...] have found interesting opening to the formal data, encouraging the analysis of ornamental details, capable, more than anything, to unveil the nature of the reciprocal mutations of the individual artefacts" [II].

Starting from these studies a cataloguing and typing of the ornamental detail, based only on the formal data, has been done. The identified categories are: orbiculi, lozenges, squares, stripes, crosses, nimbi. Each element has been organised from the simplest to the most complex. The combination of few elements can generate a multiplicity of decorations.

The orbiculi, for example, are decorations based on the circle. They simulate the adornments of the byzantine silk of Sasanian derivation. The simplest decoration is made by six or seven 'pearls' little white dots placed all around the centre. In some cases the centre is a little circumference, the dots are full or empty, surrounded by one or more circle. The combination of the same element, a circle, generates many decorations. The orbiculi often decorates the vestments of the female saints, such as Saint Margherita in Mottola, or of

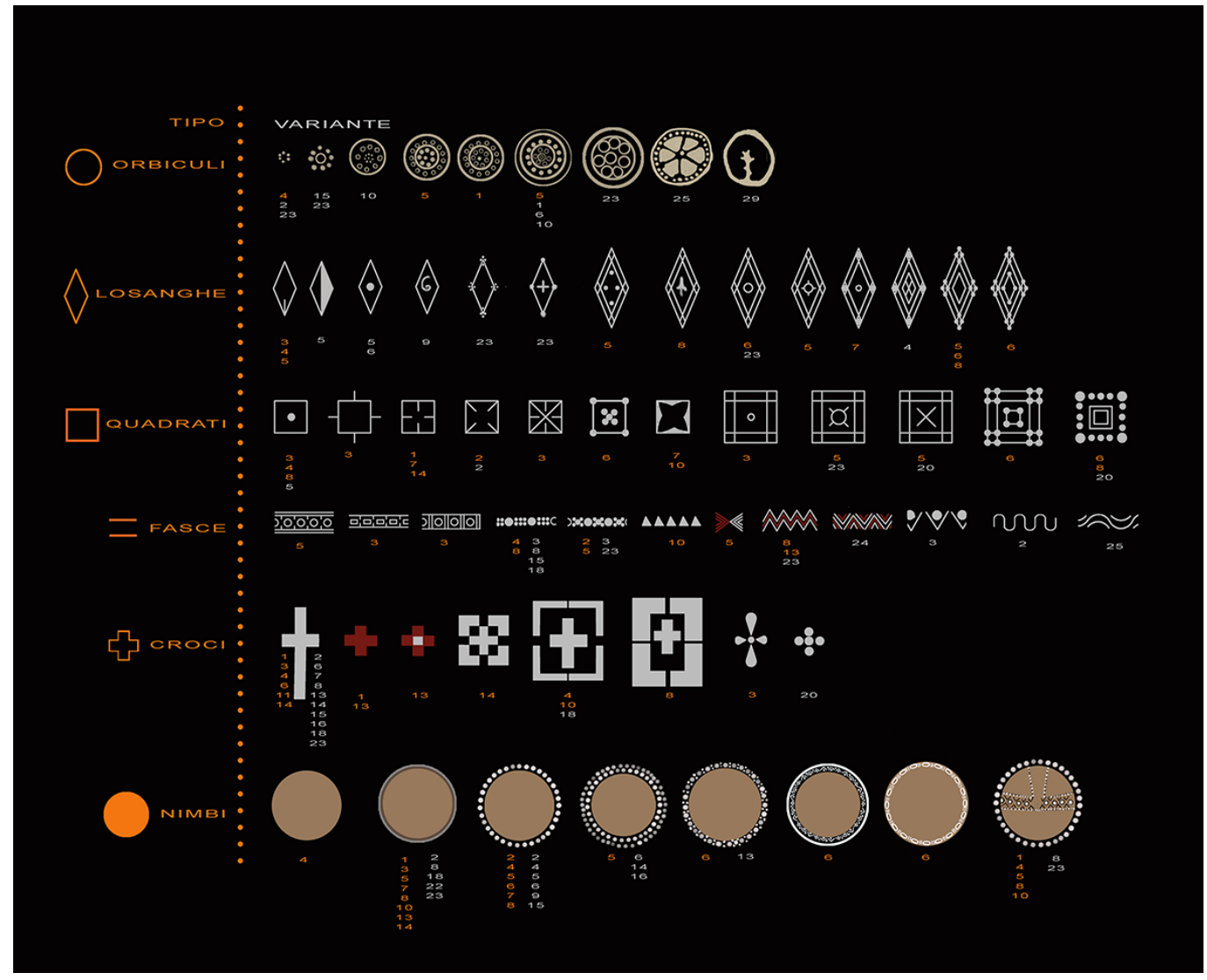


the bishop; they permit a richer and more interesting representation of the maphorion or of the sakkos.

The lozenges are subdivided in two large categories: the ones with only one contour-line and the ones with two or three contour-lines. The first ones are differentiated by the internal part: a little circle, one spiral, a little sign that represents a lily. In this category little light dots, pearls, mark the edges. The lozenges with two or three contour-lines repeat the pattern of the first: have little elements drawing in the internal surface and pearls which mark the corners.

The squares, often oblique, show many different decorations. In the middle part of each side little dashes stretch towards the internal or external part of the square while in other cases the lines mark the diagonal. Some have a quincunx pattern: four pearl placed in the corners of a square and one in the middle. The squares with two contour-lines have in the middle: a circle, a little cross or a concentric series of squares with the corner decorated by pearls.

The stripes are made with linear drawings: a series of squares with a little circle in the middle, or zigzag patterns. Others strips are made with pearls that form quincunx patterns or series of six.

Lastly we find stripes composed by full triangles or by sinuous lines. The crosses, which symbolise the Christian faith, in the Byzantine frescoes have a decorative connotation. The Latin crosses, with an elongated descending arm, ornate the omophorion, which is a vest-

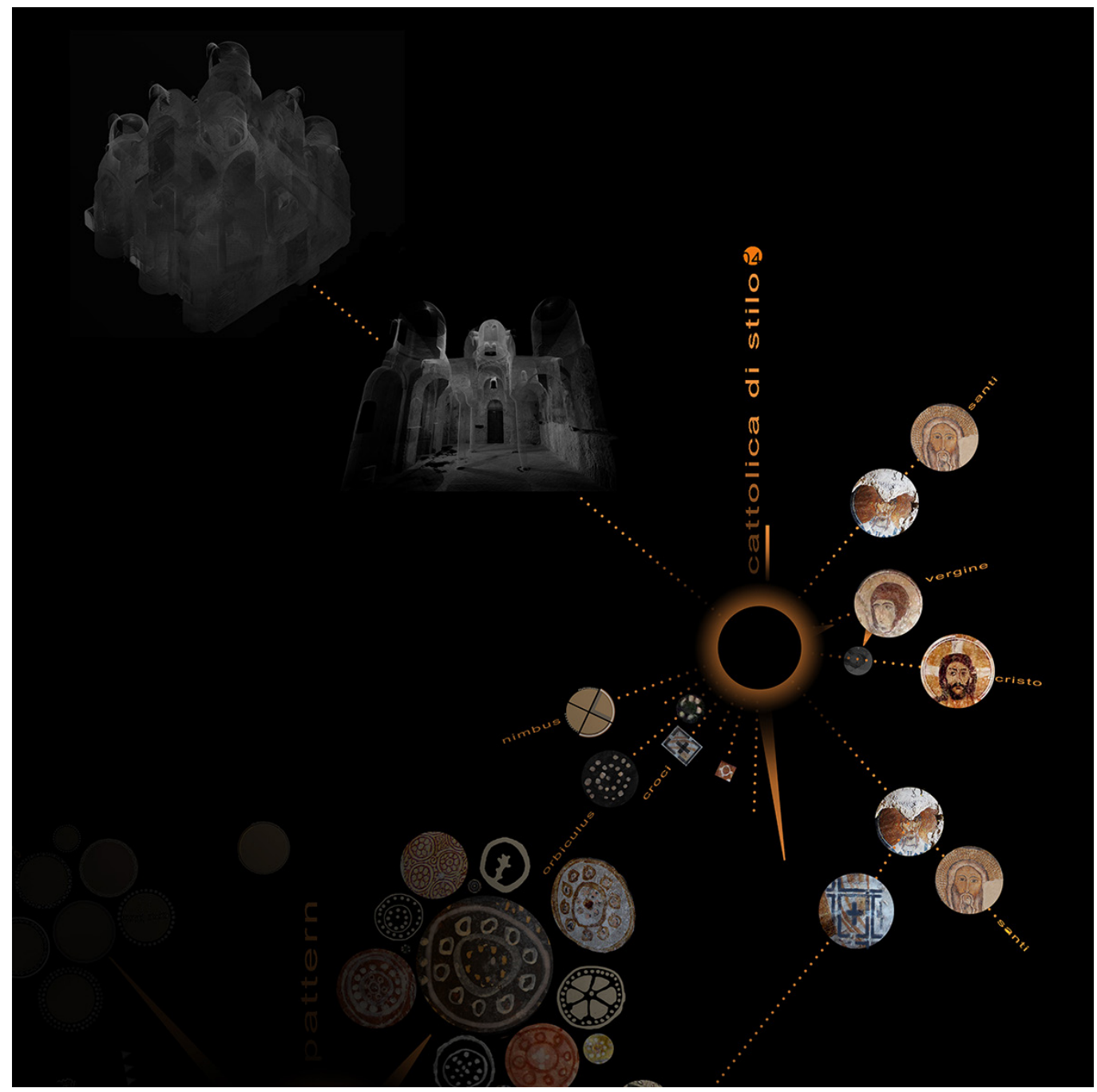




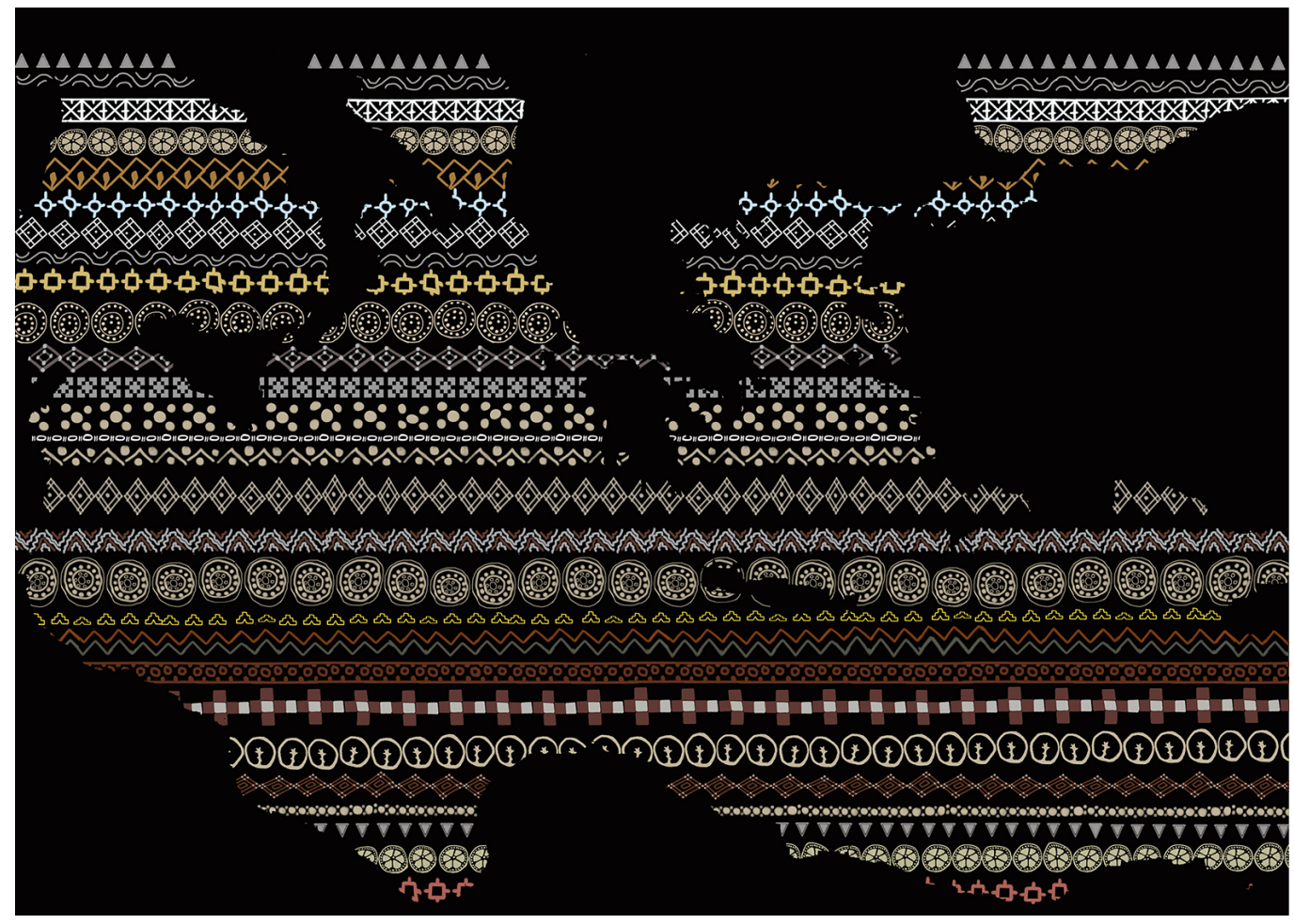

ment which underlines the role of the Good Shepard of the bishop. The Greek crosses cover the sakkos, polistavrion, of the saints which were bishops or fathers of the Eastern Church; some of them are simple, made with five square modules, others are enclosed into open frames which form, replicating the same drawing, bigger crosses. Sporadic are the crosses with pearls or with a teardrop arm.

Finally we find the nimbi starting from the simpler, without a contour-line, moving to the more complex and richer: pearled nimbi with one or more circles of pearls. The edges of the nimbi show in some cases striped decorations made with triangles alternating with pearls or ellipses alternating with double dashes. The crusade nimbus is usually dedicated to Christ; the crosses can be simple or decorated in the same way as the nimbus border.
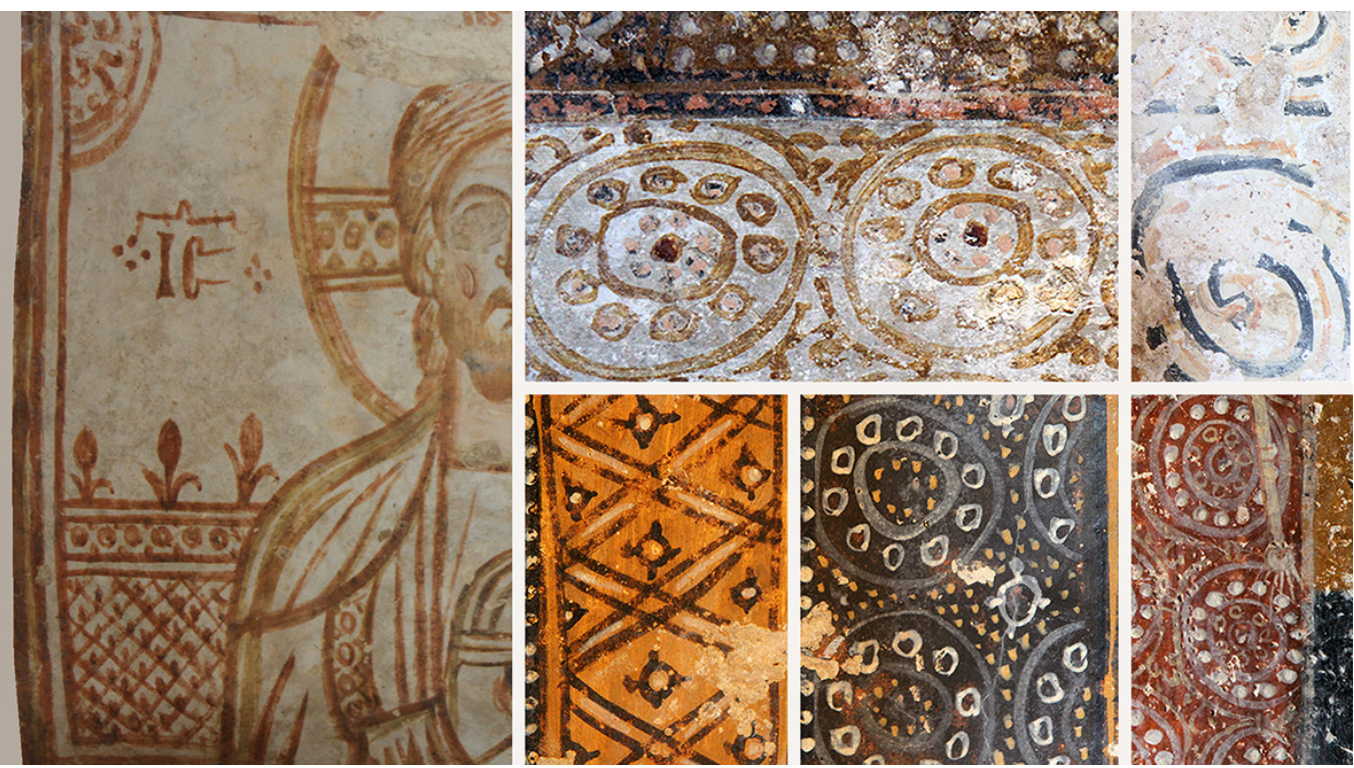


\section{Conclusion}

The patterns of this research are like the ancient byzantine fabrics: precious, dense and fragile. They are made by dust, lime and pigment: despite their apparent immobility and rigidity they stretch in space and in time to evoke assonances, to illuminate connections, to interweave relationships between shapes and colours. They create an interweaving that, maybe, we will never able to disentangle, but which is beautiful to get lost in (fig. 8).

\section{Notes}

[I] In reality the study is part of a wider research, Between lonian and Aegean conducted with Daniele Colistra and Domenico Mediati, which has seen the survey of many sacred buildings from the Byzantine era.

[2] See: Grabar 1964, p. 14. "The style of all these paintings [...] reconnects for a thousand threads to the oldest works of Cappadocia" [Grabar 1964), p. I50-I52]

[3] In the Byzantine rite churches, both those above ground and those excavated, there is a close correlation between space and the sequence of images. The order and placement of the sacred images, which take a defined structure around the twelfth century, are designed to reiterate that the material church is a figure of the spiritual one. See: Florenskij 1922.

The canonical representations are: the Christ Pantocrator or in Déesis, often placed in the apse basin; the Virgin, Odigitria Glycophilousa (of tenderness) or Kyriotissa (queen) appears in the immediate vicinity of the apse or in parts similar to a rough stone iconostasis. In the churches, we often find the figure of the archangel Gabriel and Saint Michael chasing away the dragon. Furthermore, the representation of the fathers of the Eastern Church, San Basilio Magno, San Gregorio Nazianzeno, San Giovanni Crisostomo, suggests a connection with the monastic communities of Cappadocia.

[4] See: Grabar 1964, pp. 27, 28

[5] Geometric patterns are often used to decorate the saints' robes, to identify them, or to create subdivisions within the pictorial surfaces. Byzantine visual culture, as we know, crossed the borders of the empire and imposed itself through religion and the trade in luxury goods. Among the latter, the most sought after was silk. Complex trade agreements gave the Byzantine Empire primacy over its trade. The precious silks reproduce Persian and Sassanid decorative motifs and are capable of conveying, in depth, Byzantine iconographic syncretism.

[6] Below is the list of surveys and references ordered from west to east.

Surveys: 01_Chiesa del Crocifisso_Lentini, Siracusa; 02_Chiesa Madre 7 Savoca Messina; 03 Chiesa di S. Adriano San Demetrio Corone_Cosenza; 04_Cattolica_Stilo_Reggio Calabria; 05_Santa Margherita_Mottola_Taranto; 06_San Nicola_ Mottola_Taranto; 07_San Gregorio_Mottola_Taranto; 08_San Lorenzo_Fasano_Brindisi; 09_San Giovanni_Fasano_Brindisi; I0_Eremo S.Anargyri_Agia_Larissa; I I_Eremo S. Pantaleimon_Melivoia_Larissa; I 2_Monastero S. Pantaleimon_Agia_Larissa; 13_Chiesa della Vergine_Kato Polidendri_Larissa; I4_Chiesa della Vergine_Velika_Larissa.

References: I_Abbazia di Santa Croce_Polizzi Generosa_Palermo; 2_Chiesa dello_Spedale_Scalea_Cosenza; 3 Chiesa di San Zaccaria_Caulonia_Reggio Calabria; 4_Santa Lucia_Melfi_Potenza; 5_Chiesa della Panaghia_Rossano Calabro_Cosenza; 6_Santa Lucia alle Malve_Matera; 7_San Nicola dei Greci__Matera; 8_Chiesa San Biagio a San Vito dei Normanni_Brindisi; 9_Chiesa Santa Croce__Massafra_Taranto; I0_Chiesa rupestre Madonna della Buona Nuova_ Massafra_Taranto; I I_Chiesa di Santa Barbara_Ginosa_Taranto; 12_Chiesa di San Leonardo_Ginosa_Taranto; I3_Chiesa di San Vito_Gravina in Puglia_ Lecce; I4_Cripta del Crocifisso_Ugento_Lecce; I5_Chiesa rupestre delle Sante Marina e Cristina_Carpignano_Lecce; I6_ Chiesa rupestre di Santa Maria degli Angeli_Poggiardo_Lecce; 17_San Giorgio_Kurbinovo_Macedonia; 18_Chiesa Boyana_ Sophia; 19_Chiesa della Koimesis_Asinou_Cipro; 20_Hagia Sophia_Istanbul; 2 I_S. Salvatore in Chora_Istanbul; 22_Chiesa san Nicolā Derme Antalia; 23 Karanlīk Kilise Goreme Cappadocia; 24 Yilannli Kilise Cappadocia; 25 Kokar Kilise Cappadocia; 26_Purenlì Seki Kilise_Cappadocia; 27_Bahattin Samanligi Kilise_Cappadocia; 28_Sumbullu Kilise_Cappadocia; 29_Direkli Kilise_Cappadocia.

[7] In the cave church of Saint Nicholas we also find the representations of the Virgin,Theotókos Odigitria (showing the way),

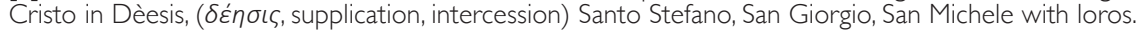

[8] 'Pursuing the 'representation' rather than the 'imitation', Byzantine artists used a limited range of forms. Within these stylistic norms they changed the physical appearance by modelling the shape of the head and the outline of the cheeks. They used lighter or darker pigments to achieve different skin tones. A wider colour and variety of form was possible in depicting hair and beard. They could be dark, red or white, long or short, whereas the absence of beard and moustache was meant to suggest young age. This method allowed the creation of a very limited number of face-types. This is confirmed by monotonous descriptions in iconographic manuals and eikonismos collections." In Piotr Ł. Grotowski (20 I 0). pp. I 37 - I 38

[9] Lama D'Antico, Fasano. Virtual restoration with video-mapping by Giuseppe Donvito, Massimo Limoncelli and Maria Potenza.

\section{References}

Beckwith John (1967). L'arte di Costantinopoli, una introduzione all'arte bizantina (330-1453). Torino: Einaudi (I Ed. The art of Constantinople, An Introduction to Byzantine Art. London: Phaidon Press, I96I).

Florenskij Pavel A. (2002). Le porte regali. Saggio sull'icona, a cura di E. Zolla, Milano: Adelphi.

Fonseca Cosimo Damiano (1970). Civiltà rupestre in terra jonica. Milano: Carlo Bestetti Edizioni.

Grabar André (1964). Bisanzio. (traduzione Silvia De Cesaris). Milano: Il Saggiatore. (I Ed. Byzance. Baden: Holle Verlang, 1964). 
Grotowski Piotr Ł. (20 I0). Defining the Byzantine Saint, Creating a Message in Orthodox Art in Towards Rewriting? New Approaches to Byzantine Archaeology and Art. Warsaw: Edited by P. Ł. Grotowski and S. Skrzyniarz.

Innemée Karel C. (1992). Ecclesiastical Dress in the Medieval Near East. Leiden: Brill.

Lentini Pasquale (1988). Il fenomeno della civiltà rupestre nel territorio di Mottola. Galatina: Congedo.

Maronidis A., Voutounos C., Lanitis A. (2014). Designing and Evaluating an Expert System for Restoring Damaged Byzantine Icons. In Multimedia Tools and Applications, June 20I4. New York: Springer Science+Business Media.

Medea Alba (20|4). Gli affreschi delle cripte eremitiche pugliesi. Lecce: Capone

Scalzo Marcello (2002). Sul rilievo di architetture rupestri. Firenze-Massafra: Archeogruppo.

Settis Salvatore (2005). Iconografia dell'arte italiana I 100- I 500: una linea. Torino: Einaudi.

Thierry N., M. Hierry (1963). Églises rupestres de Cappadoce, région du Hasan Dagi. Paris: Librairie Klincksieck.

\section{Author}

Marinella Arena, Università degli Studi Mediterranea di Reggio Calabria, marinella.arena@unirc.it

To cite this chapter. Arena Marinella (2020). Connessioni geometriche: per una catalogazione fantastica dei pattern bizantini/Geometrical Connections: for a 'fantastic' cataloguing of Byzantine patterns. In Arena A., Arena M., Brandolino R.G., Colistra D., Ginex G., Mediati D., Nucifora S. Raffa P. (a cura di). Connettere. Un disegno per annodare e tessere. Atti del $42^{\circ}$ Convegno Internazionale dei Docenti delle Discipline della Rappresentazione/Connecting. Drawing for weaving relationships. Proceedings of the 42th International Conference of Representation Disciplines Teachers. Milano: FrancoAngeli, pp. 2931-2954 